\title{
Morpho-functional study of the hypothalamic proline-rich polypeptide apoptotic activity against mouse Ehrlich ascites carcinoma
}

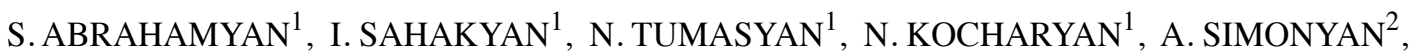

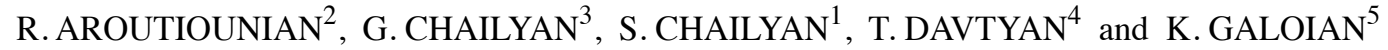 \\ ${ }^{1}$ Laboratory of Histochemistry and Functional Morphology, Institute of Biochemistry after H. Buniatian, \\ NAS RA, 0014 Yerevan; ${ }^{2}$ Department of Genetics and Cytology, Faculty of Biology, Yerevan State University, \\ 0025 Yerevan, Republic of Armenia; ${ }^{3}$ Department of Immunology, Institute for Molecular Medicine, \\ Huntington Beach, CA 92647, USA; ${ }^{4}$ Analytical Laboratory Branch, Scientific Centre of Drug and \\ Medical Technology Expertise after Academician E. Gabrielyan CJSC, 0051 Yerevan, Republic of Armenia; \\ ${ }^{5}$ Department of Orthopedic Surgery, University of Miami, Miller School of Medicine, Miami, FL 33136, USA
}

Received April 12, 2019; Accepted March 20, 2020

DOI: $10.3892 /$ or.2020.7604

\begin{abstract}
A new type of bioactive polypeptides of the neurosecretory hypothalamus called proline-rich peptides (PRPs), which are isolated from bovine neurosecretory granules of the neurohypophysis, are synthesized in the form of a common precursor protein (neurophysin vasopressin-associated glycoprotein). Proline-rich polypetide 1 (PRP-1; also known as galarmin) is comprised of 15 amino acids residues, and has been suggested to possess anti-neurodegenerative, immunoregulatory, hematopoietic, antimicrobial and antitumor properties. The cytostatic, antiproliferative effect of PRP-1 was demonstrated in the human chondrosarcoma JJ012 and triple negative breast carcinoma MDA MB 231 cell lines. PRP-1 action is disease and tissue specific. To further explore the antitumorigenic and possible cytotoxic effects of PRP-1, a morpho-functional study on the effect of PRP-1 on a mouse Ehrlich ascites carcinoma (EAC) model was conducted. The PRP-1-induced morphological features of EAC cells confirmed the apoptotic nature of PRP-1, as manifested by cell shrinkage, membrane blebbing, chromosome condensation (pyknosis) and nuclear fragmentation (karyorrhexis). The effect of PRP-1 on the number of tumor cells incubated for $24 \mathrm{~h}$ and their viability
\end{abstract}

Correspondence to: Dr K. Galoian, Department of Orthopedic Surgery, University of Miami, Miller School of Medicine, 1600 NW 10th Avenue, S 8012, Miami, FL 33136, USA

E-mail: kgaloian@med.miami.edu

Dr S. Abrahamyan, Laboratory of Histochemistry and Functional Morphology, Institute of Biochemistry after H. Buniatian, NAS RA, P. Sevak 5/1, 0014 Yerevan, Republic of Armenia

E-mail: silva.abrahamyan@gmail.com

Key words: PRP-1, galarmin, Ehrlich ascites carcinoma, mice, histology, fluorescence, apoptosis, Annexin V-Cy3 in trypan blue-stained samples lead to a $44 \%$ reduction in the number of viable cells on day 11 post-inoculation vs. $22 \%$ inhibition of viable cells after PRP-1 treatment $(0.1 \mu \mathrm{g} / \mathrm{ml})$ on day 7 post-inoculation. Apoptosis experiments using an Annexin V-cyanine 3 apoptosis detection kit indicated that $24 \mathrm{~h}$ incubation with $0.1 \mu \mathrm{g} / \mathrm{ml}$ PRP-1 caused a significant increase in the number of apoptotic cells, reaching $50.33 \%$, compared to $8.33 \%$ in the sample control on day 7 post-inoculation.

\section{Introduction}

A new type of bioactive polypeptides of the neurosecretory hypothalamus, the proline-rich polypeptides (PRPs), were isolated in 2001 from bovine neurohypophysis neurosecretory granules $(1,2)$. PRPs are synthesized from a common precursor, namely neurophysin vasopressin-associated glycoprotein. The mTORC1 inhibitor proline-rich polypetide 1 (PRP-1; also known as galarmin) is a short 15-amino acid neuropeptide (sequence, Ala-Gly-Ala-Pro-Glu-Pro-Ala-Glu-Pro-Ala-Gl n-Pro-Gly-Val-Tyr) with neuroprotective, immunomodulatory $(3,4)$, antiviral, anti-inflammatory $(5)$, antibacterial $(6)$, hematopoietic (7) and antitumor properties (8-10,11-14).

PRP-1 was identified as a ligand for innate immunity pattern recognition Toll-like receptors 1,2 and 6 , and the mucosal protein mucin 5B (15). PRP-1 caused significant upregulation of tumor suppressor genes and miRNA with tumor suppressor function and downregulation of onco-miRNAs in the human chondrosarcoma JJ012 cell line $(11,13)$. The antiproliferative effect of PRP-1 was caspase-3-independent and cytostatic by nature in the bulk human chondrosarcoma cell population (16) and in triple negative breast cancer (10). The antitumor function of PRP-1 was demonstrated to be organ-specific, since it did not display any effect on glioblastoma (12).

The Ehrlich ascites carcinoma (EAC) is a common undifferentiated tumor with rapid growth rate and sensitivity to chemotherapy (17). Ehrlich tumors originate from spontaneous murine mammary adenocarcinomas and adapt to ascites form 
by intraperitoneal (ip) serial passages. The EAC model is widely used in experimental cancer due to its high efficiency in producing free neoplastic cells and its accuracy in terms of survival time (18). The aim of the present study was in vitro exploration of the effect of PRP-1 on EAC cells collected from the ascitic fluid of EAC cell-bearing mice.

\section{Materials and methods}

EAC mouse model. The ascitic fluid of [2 to 3-month-old male white Swiss $(\mathrm{SWR} / \mathrm{J})$ mice weighing $20 \pm 2 \mathrm{~g}$ ] with the EAC model was provided by the Laboratory of Toxicology and Experimental Chemotherapy (Institute of Fine Organic Chemistry, National Academy of Sciences of Armenia). Mice were inoculated with EAC-E2G8 tumor cells (obtained by the Hebei Medical University scholars from the Beijing Cancer Institute EAC) to produce the EAC model.

The ascitic fluid containing the EAC cells was obtained from the peritoneal cavity of mice on days $7(n=10)$ and $11(n=10)$ after tumor growth, and then used for in vitro experiments at the laboratory of Histochemistry and Functional Morphology (Institute of Biochemistry after H. Buniatian, NAS RA).

Culture of cell suspension. The EAC cell suspensions obtained from the peritoneal cavity of mice (which closely mimic in vivo conditions) and suspensions containing EAC cells isolated by centrifugation were used. Ascitic fluid was centrifuged at $300 \mathrm{x} \mathrm{g}$ for $5 \mathrm{~min}$ at $18-20^{\circ} \mathrm{C}$.

Then, the supernatant was discarded, and the cells were washed in Hanks' Balanced Salt Solution buffered with phosphate (pH 7.4) (cat. no. 55037C; Sigma-Aldrich; Merck $\mathrm{KGaA}$ ). Subsequently, the cells were re-suspended in Hanks' Balanced Salt Solution to a concentration of $5 \times 10^{6}$ cells $/ \mathrm{ml}$ in RPMI-1640 medium and grown in tissue culture dishes until $\sim 80 \%$ confluence in RPMI-1640 culture medium (BioloT, Ltd.) containing $10 \%$ heat-inactivated fetal bovine serum, $50 \mathrm{U} / 1$ penicillin and $1 \%$ L-glutamine. The cell suspensions were incubated at $37^{\circ} \mathrm{C}$ and $5 \% \mathrm{CO}_{2}$ with constant shaking. Control samples $(n=3)$ untreated with PRP-1 and experimental samples with single administration of $0.1 \mu \mathrm{g} / \mathrm{ml}$ PRP-1 $(\mathrm{n}=3)$ and $1 \mu \mathrm{g} / \mathrm{ml}$ PRP-1 $(\mathrm{n}=3)$ were cultured for 24 and $72 \mathrm{~h}$ in unchanged culture medium. Daily quantification of the total and viable number of EAC cells was carried out. Each condition was tested in triplicate.

Tumor cell count. For the culture of EAC cells, $5 \times 10^{6}$ cells were obtained from the suspension containing numerous tumor cells, by diluting it in RPMI-1640 medium. The cells were counted in a Neubauer chamber (19).

Histological and immunohistological staining. A light digital microscope (M10; Motic) was used for histological and immunohistochemical investigations.

\section{Histological staining}

Trypan blue ( $\mathrm{Tr}-\mathrm{Bl}$ ) staining. The number of viable cells in the suspension was determined by the method of exclusion with trypan blue (diazo live dye, at a concentration $0.4 \%$ ) (20). Using the Tr-Bl staining method, the percentage of dead and alive cells was calculated after $24 \mathrm{~h}$ of incubation in the control samples and those treated with PRP-1 at 0.1 and $1 \mu \mathrm{g} / \mathrm{ml}$ concentrations.

Haematoxylin and eosin $(H \& E)$ staining. EAC suspension smears were fixed in $96 \%$ ethanol for $10 \mathrm{~min}$ at room temperature; dehydrated by passing through decreasing concentrations of alcohol baths (96 and 75\%) and distilled water, stained in haematoxylin for $5 \mathrm{~min}$ at room temperature, washed in tap water for $\leq 5 \mathrm{~min}$, stained in $1 \%$ eosin for $1 \mathrm{~min}$ at room temperature, washed in tap water for $2 \mathrm{~min}$, dehydrated in increasing concentrations of ethanol (75 and 96\%), cleared in xylene two times, and mounted with DPX (cat. no. 06522; Sigma-Aldrich; Merck KGaA) (21).

Giemsa staining. For staining the smears of the EAC cell suspension, Giemsa stain was used at a 1:20 ratio. To produce a 1:50 dilution of Giemsa stain, $1 \mathrm{ml}$ stock solution of Giemsa stain was added to $49 \mathrm{ml}$ phosphate-buffered (pH6.4) solution. The smears were dried in air and covered in DPX (22).

Papanicolaou staining. A drop of the EAC cell suspension was spread on a glass slide, dried in air and fixed in $95 \%$ ethyl alcohol for $30 \mathrm{~min}$ at room temperature. Slides were then incubated in 70 and $50 \%$ ethanol followed by distilled water, stained in Harris hematoxylin for $4 \mathrm{~min}$ at room temperature, rinsed briefly in warm $\left(20-30^{\circ} \mathrm{C}\right)$ distilled water for $4 \mathrm{~min}$, placed in tap water for $6 \mathrm{~min}$, rinsed in distilled water, and incubated in 50, 70, 80 and 95\% ethanol. Then, the slides were stained in EA-50 for 2 min at room temperature; rinsed three times with $95 \%$ ethanol, dehydrated in absolute alcohol, followed by equal parts of absolute alcohol and xylol, cleared in xylol, and mounted with DPX (23).

Fluorescence microscopy. Determination of the tumor cell apoptosis rate was performed using the Annexin V-Cy3 apoptosis Detection Kit (product no. APOAC; Sigma-Aldrich $\mathrm{KGaA}$ ). The non-fluorescent compound 6-carboxyfluorescein diacetate (6-CFDA) enters viable cells, is hydrolyzed by esterizes to the fluorescent compound 6-carboxyfluorescein (6-CF) and then retained in the cytoplasm. Dead cells do not exhibit uptake of 6-CFDA and have an increased efflux of the free 6-CFDA. The apoptosis assay is based upon double staining with cyanine 3 (Cy3)-conjugated Annexin V and the vital dye 6-CFDA. The assay discriminates viable cells $\left(\mathrm{Cy} 3 / 6-\mathrm{CF}^{+}\right)$from apoptotic $\left(\mathrm{Cy}^{+} / 6-\mathrm{CF}^{+}\right)$and dead (necrotic) cells $\left(\mathrm{Cy} 3^{+} / 6-\mathrm{CF}\right)$. There are three possible outcomes: i) living cells that only stain with 6-CF (green); ii) necrotic cells that only stain with AnnexinV-Cy3 (red); and iii) cells starting the apoptotic process, which stain both with Annexin V-Cy3 (red) and 6-CF (green), resulting in yellow-orange stain (24). A total of 400 cells/sample were analyzed. Data represent 3 independent experiments (25).

The nuclear counterstain method with DAPI fluorescent staining dye (cat. no. D1306; Thermo Fisher Scientific, Inc.) was used to confirm the PRP-1 nuclear localization in the cultured EAC cells and detection was performed using the ABC immunohistochemical method.

Immunohistochemical staining. The avidin-biotin complex (ABC) immunohistochemical method was applied for 

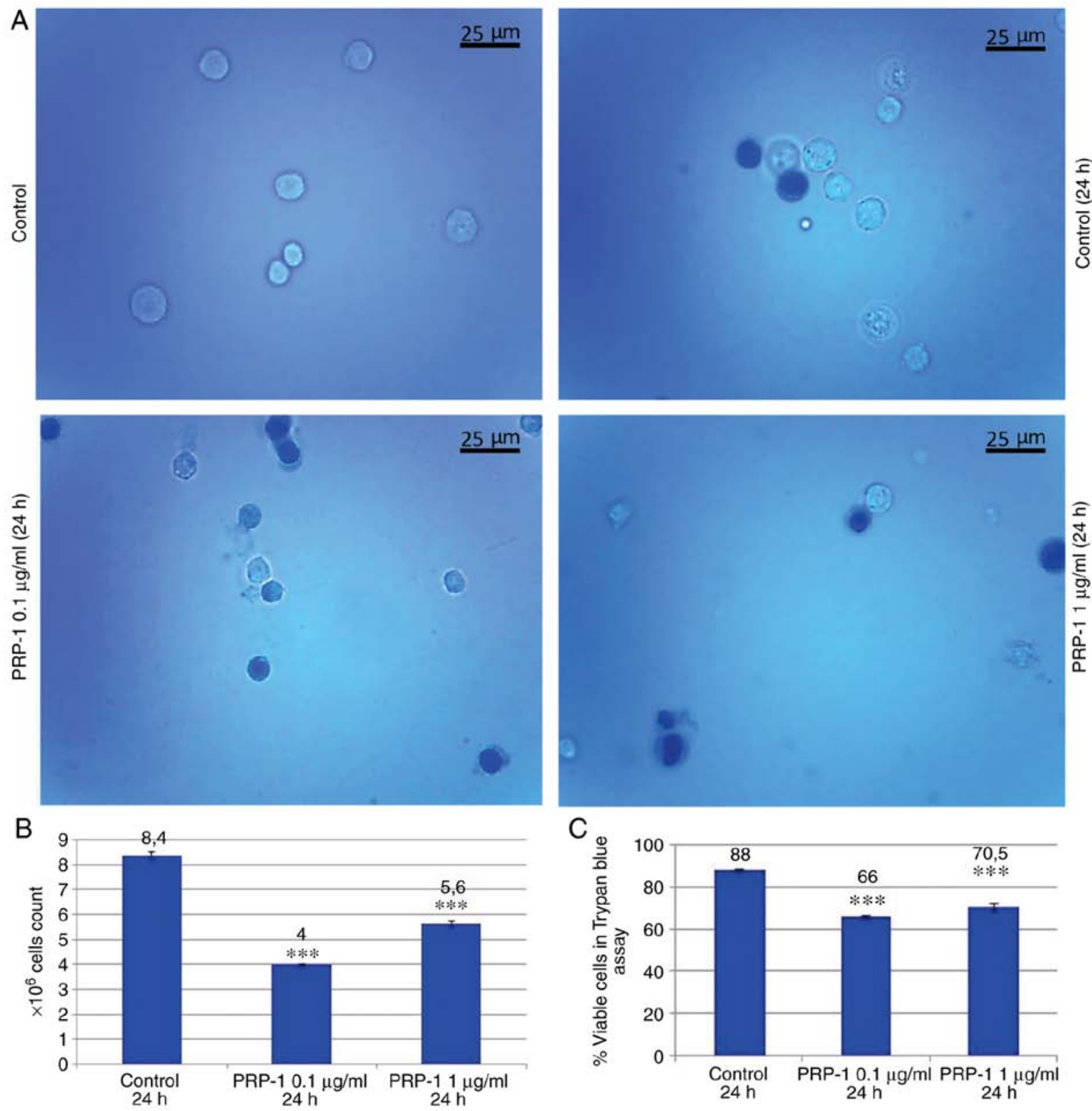

Figure 1. Effect of the hypothalamic PRP-1 on the growth and viability of mouse isolated EAC cells on the 7th day of tumor growth: Histological method with Tr-Bl staining. (A) Viable EAC cells were revealed in the control samples before their culture (control). Various dead Tr-Bl-positive tumor cells were detected among the viable cells in the non-treated control samples $24 \mathrm{~h}$ after culture (control $24 \mathrm{~h}$ ). An increased number of Tr-Bl-positive dead cells was evident $24 \mathrm{~h}$ after 0.1 and $1 \mu \mathrm{g} / \mathrm{ml}$ PRP-1 administration. The PRP-1 inhibitory effect $(0.1$ and $1 \mu \mathrm{g} / \mathrm{ml})$ on the number of (B) total and (C) viable tumor cells treated for $24 \mathrm{~h}$ was statistically significant according to the Tr-Bl exclusion test in comparison with the findings in the untreated control cells. Data are presented as the mean \pm standard deviation $(\mathrm{n}=3)$, and represent $\geq 3$ independent experiments. ${ }^{* * *} \mathrm{P}<0.001$, significant difference compared to the control at $24 \mathrm{~h}$. Tr-Bl, trypan blue; PRP, proline-rich peptide; EAC, Ehrlich ascites carcinoma.

detection of PRP-1 localization in cancer cells using antiserum produced at our laboratory (Institute of Biochemistry NAS, Armenia) against synthetic PRP-1 (26). After rinsing several times in PBS, the samples were treated with Triton X-100 for $45 \mathrm{~min}$ to permeabilize, $0.3 \%$ hydrogen peroxide for $30 \mathrm{~min}$ to suppress the background peroxidase activity, and normal goat serum (1:30; cat no. S-1000; Vector Laboratories, Inc.) for 45 min to block non-specific binding of antibodies. Then, the samples were incubated in primary antiserum [anti-PRP-1; 1:2,000; produced at the laboratory of Histochemistry and Functional Morphology (Institute of Biochemistry, NAS, Armenia)] for $24 \mathrm{~h}$ at $4^{\circ} \mathrm{C}$, secondary antiserum (biotinylated goat anti-rabbit immunoglobulin; 1:200; cat. no. BP-9100) for
45 min; and streptavidin (1:100; cat. no. SA-5000; both from Vector Laboratories, Inc.) for $45 \mathrm{~min}$ at room temperature. Immunoreactivity (IR) was revealed by $0.02 \% 3,3^{\prime}$-diaminobenzidine tetrahydrochloride (DAB) (product no. D5905; Sigma-Aldrich; Merck KGaA) and 0.6\% nickel ammonium sulfate diluted in $50 \mathrm{mM}$ Tris- $\mathrm{HCl}$ buffer (pH 7.6) in the presence of $0.03 \%$ hydrogen peroxide as an oxidant. Both primary and secondary antisera were diluted in PBS containing $0.1 \%$ bovine serum albumin (BSA) (product no. 05470; Sigma-Aldrich; Merck KGaA) and $0.01 \%$ sodium azide. All incubations, except for the incubation with normal goat serum, were separated by washes in PBS. The slides were mounted in DPX medium and the results were analyzed using light 

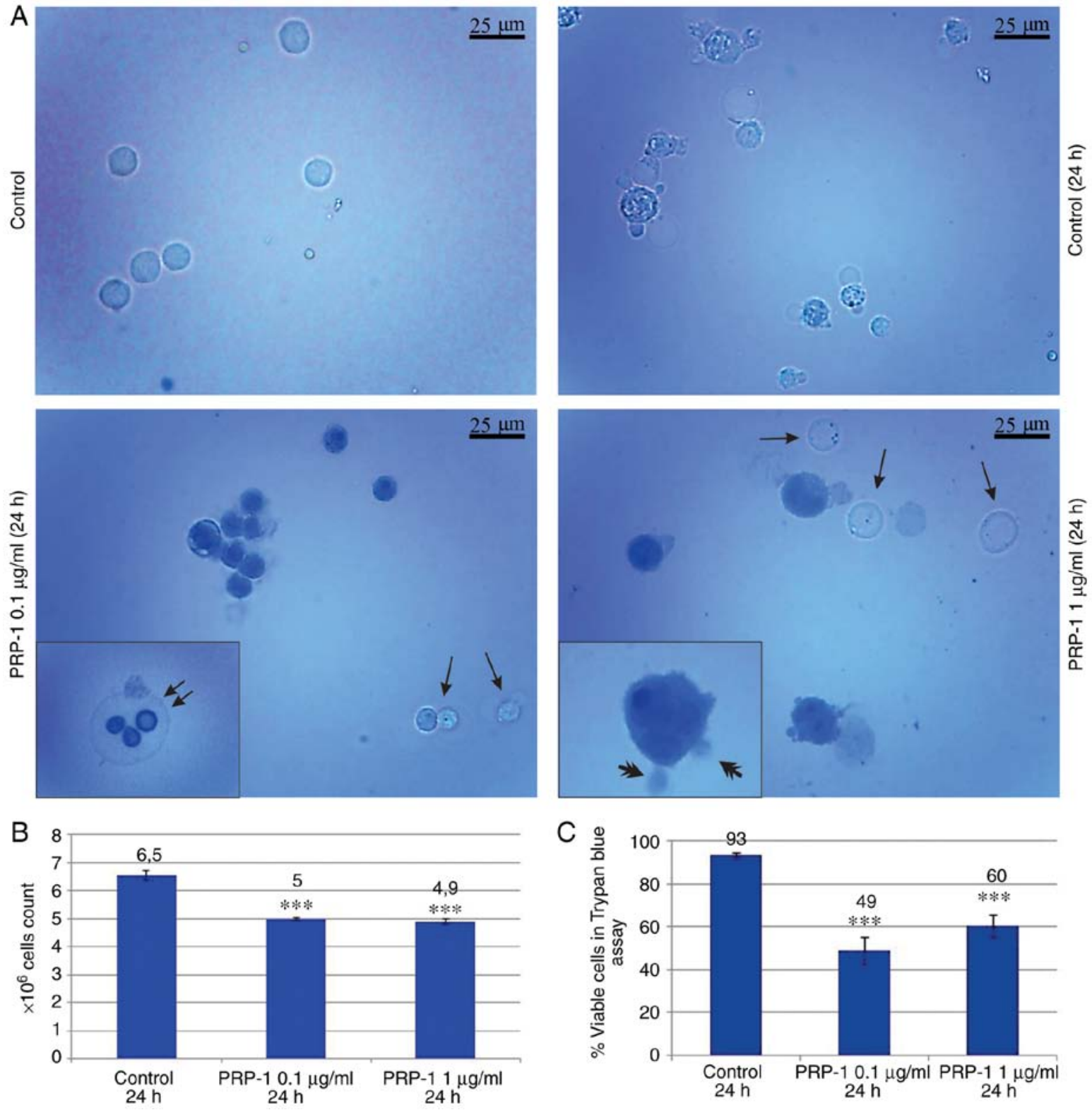

Figure 2. Effect of the hypothalamic PRP-1 on the growth and viability of mouse isolated EAC cells on the 11th day of tumor growth: Histological method with Tr-Bl staining. (A) Viable EAC cells were detected before their culture (control). EAC control cells after $24 \mathrm{~h}$ of incubation were mainly viable, although various dead Tr-Bl-positive cells were present (control $24 \mathrm{~h}$ ). In samples treated with 0.1 and $1 \mu \mathrm{g} / \mathrm{ml} \mathrm{PRP-1}$, an increased number of Tr-Bl-positive non-viable cells was detected, along with various viable cells (arrows), apoptotic cells with fragmented nuclei (double arrows) and various Tr-Bl-positive cells surrounded by apoptotic bodies (arrow heads). The PRP-1 inhibitory effect $(0.1$ and $1 \mu \mathrm{g} / \mathrm{ml})$ on the number of (B) total and (C) viable tumor cells treated for $24 \mathrm{~h}$ was statistically significant according to the Tr-Bl exclusion test in comparison with the findings in the untreated control cells. Data are presented as the mean \pm standard deviation $(\mathrm{n}=3)$, and represent $\geq 3$ independent experiments. ${ }^{* * *} \mathrm{P}<0.001$, significant difference compared to the control at $24 \mathrm{~h}$. Tr-Bl, trypan blue; PRP-1, proline-rich polypeptide 1; EAC, Ehrlich ascites carcinoma.

microscopy at $\mathrm{x} 100, \mathrm{x} 400$ and $\mathrm{x} 1,000$ magnifications. To confirm immunospecificity for PRP-1, the primary antiserum was replaced by normal goat, phosphate buffer or PRP-1 antiserum pre-absorbed with synthetic PRP-1, synthesized at our laboratory (Institute of Biochemistry, NAS, Armenia) for the negative control experiments.

\section{PRP-1 antiserum production and affinity chromatography purification}

Antiserum production. For immunization 1 to 1.5 -year old wild male $23-4$ rabbits [Oryctolagus cuniculus (Linnaeus, 1758)] of the Californian breed, weighing $2 \mathrm{~kg}$ were used. Animal immunization was performed using pentobarbital
(Nembutal; serial no. 71308321 and registration no. 0285003) anesthesia at a dose of $30-35 \mathrm{mg} / \mathrm{kg}$. The Institutional Animal Ethics Committee of Buniatian Institute of Biochemistry of the NAS (IRB 0001621; IORG0009782) provided approval for the use of the animals. The rabbits woke up normally and behaved naturally after the procedures which lasted 10-15 min, were performed. The rabbits were housed in cages (cage model RBB-S-01) comprised of 2 sections of size, $600 \times 450 \times 450 \mathrm{~mm}$, separated by a removable partition, one animal in each section. Rabbits were maintained at a room temperature of $18-22^{\circ} \mathrm{C}$ and a relative humidity of $55-65 \%$. Rabbits were fed twice a day, morning and evening with a daily diet which consisted of: Unlimited access to hay or grass, a 

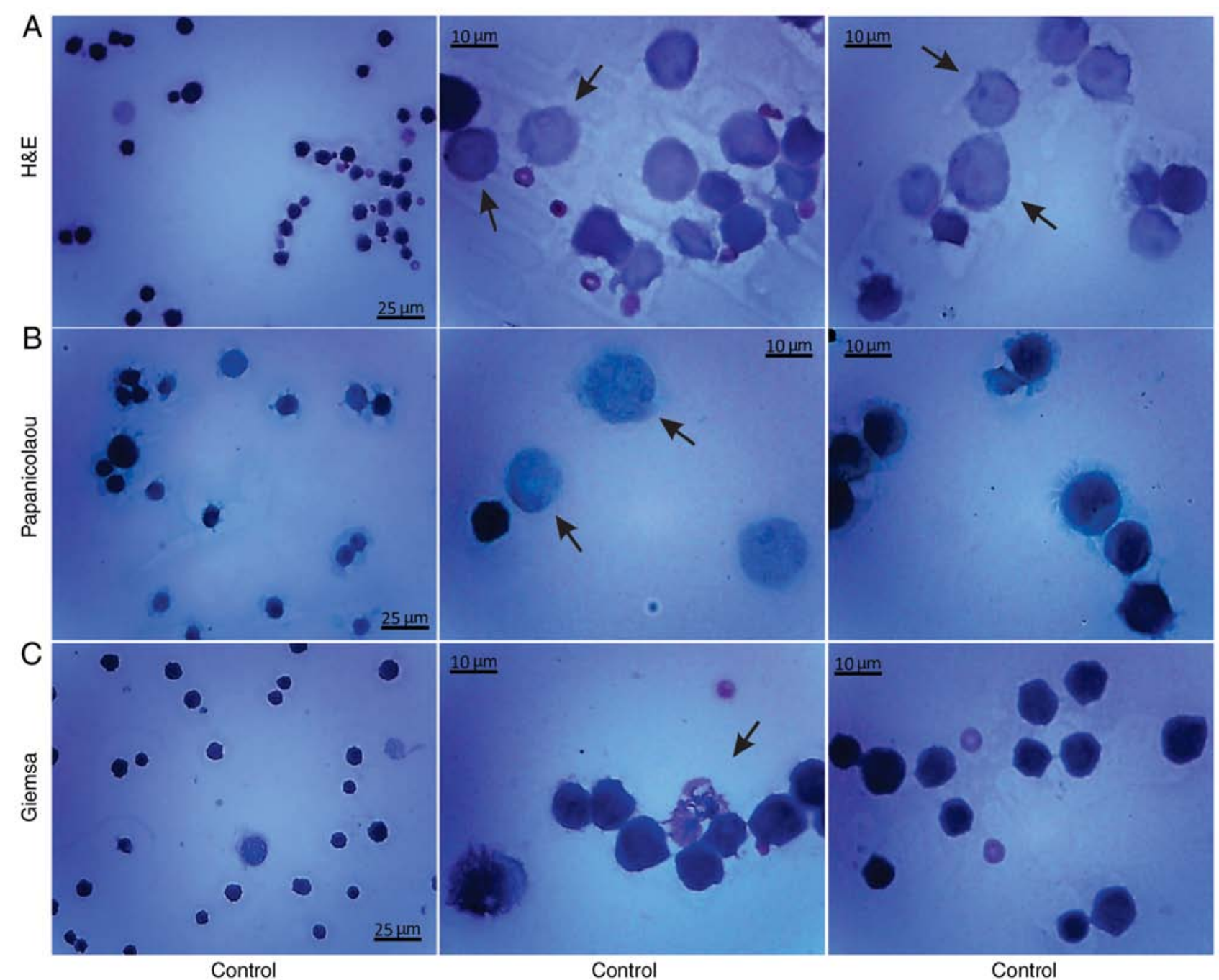

Control

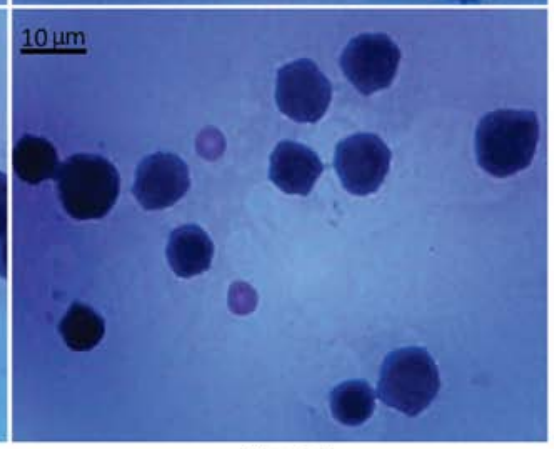

Control

Figure 3. Histological study of mouse EAC cells in suspension obtained directly from the peritoneal cavity of mice on the 7th day of tumor growth before culture: Histological methods with (A) H\&E, (B) Papanicolaou and (C) Giemsa staining. Stained in red, small erythrocytes not containing nuclei and weakly-stained macrophages (arrows) were observed next to strongly-stained EAC cells. EAC, Ehrlich ascites carcinoma; H\&E, hematoxylin and eosin.

handful of fruits, vegetables or leafy plants and a small amount of high-quality commercial mix (for rabbits) or granules (up to $25 \mathrm{~g}$ per $\mathrm{kg}$ of rabbit body weight). The rabbits were used once more to obtain a new portion of PRP-1-antiserum with higher titration.

Antiserum against synthetic PRP-1 was obtained according to the method by Ambrosius (27). The PRP-1-BSA conjugate, was mixed with $1 \mathrm{mg} / 0.2 \mathrm{ml}$ Freund's Complete Adjuvant (product no. F5881; Sigma-Aldrich; Merck KGaA), until a homogenous emulsion was achieved (28), and then injected in equal portions into the lower extremities of rabbits in the region of both popliteal lymph nodes. Immunization was repeated 1 month later by injecting a freshly prepared emulsion (1 mg PRP-1-BSA in $1 \mathrm{ml}$ phosphate buffer, $\mathrm{pH}$ 7.4) in the following locations: Into the region of the left popliteal lymph node $(0.4 \mathrm{ml})$, into the auricular vein $(0.2 \mathrm{ml})$ and, intramuscularly on the right side $(0.4 \mathrm{ml})$. After reimmunization, blood samples were obtained from the auricular vein on days 7, 9 and 11 from the rabbits, mixed and kept in the refrigerator $\left(\right.$ at $\left.+4^{\circ} \mathrm{C}\right)$. Then $10 \mathrm{ml}$ of this mixture was lyophilized. The specificity of the antiserum was tested by immunodiffusion and ELISA (29).
PRP-1 antiserum affinity chromatography purification. PRP-1 antiserum affinity chromatography purification was performed using AminoLink ${ }^{\mathrm{TM}}$ Plus Immobilization kit (Thermo Fisher Scientific, Inc.) according to the manufacturer's instructions.

Statistical analysis. Statistical analysis was performed using the statistical package Statgraphics Centurion 16.2 (StatPoint Technologies, Inc.). The results were compared with those of the control, and the Student's t-test was used to estimate the statistical significance of the data. Data were presented as the mean \pm standard deviation. $\mathrm{P}<0.05$ was considered to indicate a statistically significant difference.

\section{Results}

Histological (Tr-Bl, H\&E, Giemsa, Papanicolaou and Annexin V-Cy3 apoptosis detection stains) and immunohistochemical $(\mathrm{ABC})$ methods were used in the present study to investigate the antitumorigenic effect of PRP-1 in EAC cells. EAC suspensions, including those obtained from the peritoneal cavity of mice (since it closely resembles in vivo conditions) and those containing isolated EAC cells, were 


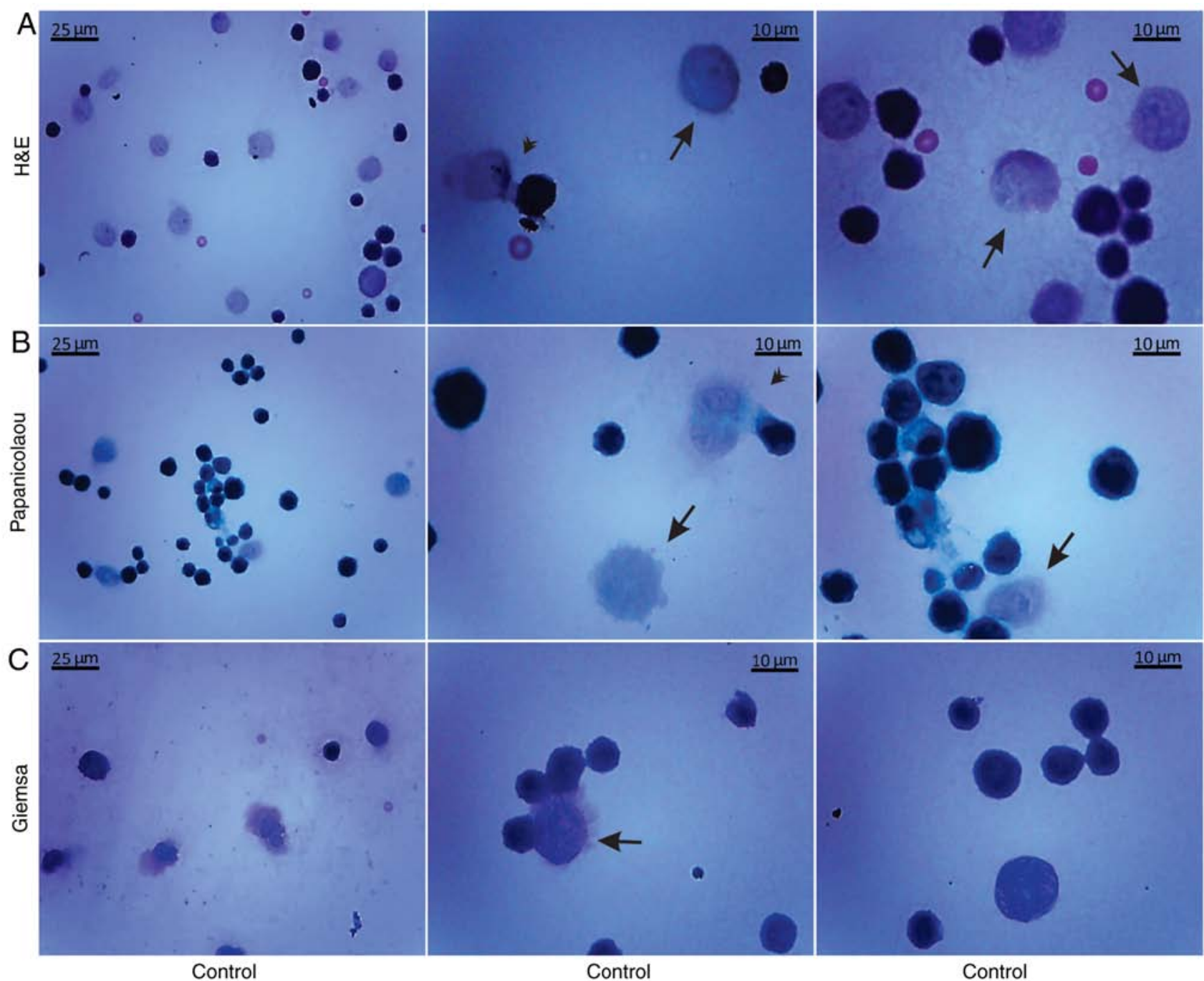

Figure 4. Histological study of mouse EAC cells in suspension obtained from the peritoneal cavity of mice on the 11th day of tumor growth before culture: Histological methods with (A) H\&E, (B) Papanicolaou and (C) Giemsa staining. Weakly-stained cells, possibly macrophages (arrows), were mainly located in close contact with strongly-stained EAC cells. Various cells exhibiting phagocytosis were also observed (arrowheads). EAC, Ehrlich ascites carcinoma; H\&E, hematoxylin and eosin.

used. The effect of 0.1 and $1 \mu \mathrm{g} / \mathrm{ml} \mathrm{PRP-1}$ was studied on the isolated EAC cells of mice on days 7 and 11 of tumor growth and cultured for 24 and $72 \mathrm{~h}$.

Histological study. Light microscopy and histological staining with Tr-Bl experiments were used to reveal the percentage of dead and alive cells after $24 \mathrm{~h}$ of incubation in the control samples and those treated with PRP-1 at the aforementioned concentrations.

Statistical analysis of the tumor growth at $24 \mathrm{~h}$ confirmed the PRP-1 antitumorigenic effect on EAC cells. Figs. 1 and 2 revealed a decrease in the number of total EAC cells when treated with PRP-1 ( 01 and $1 \mu \mathrm{g} / \mathrm{ml})$, indicating the anti-proliferative activity of PRP-1 in comparison with the findings in the $24 \mathrm{~h}$ untreated control samples. Concurrently, the number of viable EAC cells treated with PRP-1 was decreased compared with that in the control group. On day 7 post-inoculation, the number of total cells was $5 \times 10^{6}$, and increased to $8 \times 10^{6}$, with viable cells comprising $88 \%$ of the cell population, whereas in the $0.1 \mu \mathrm{g} / \mathrm{ml}$ PRP-1-treated samples, the total number of cells was reduced to $4 \times 10^{6}$, where viable cells accounted for $66 \%$ of the total population. Thus, PRP-1 inhibited the growth of viable cells by $22 \%$ (Fig. 1B and C). On day 11 post-inoculation, the total number of cells increased from $5 \times 10^{6}$ to $6.5 \times 10^{6}$, of which 93\% were viable in the $24 \mathrm{~h}$ control, while in the PRP-1-treated samples, that number was $5 \times 10^{6}$, with only $49 \%$ of viable cells, thus indicating an inhibition of viable cells by $44 \%$ caused by PRP-1 (Fig. 2B and C). The difference between the effect of 0.1 and $1 \mu \mathrm{g} / \mathrm{ml}$ PRP-1 was clearly visible when comparing the total number of EAC cells on the 7th day of inoculation indicating the more effective anti-proliferative action of $0.1 \mu \mathrm{g} / \mathrm{ml}$ PRP-1. Thus, since similar results were obtained with the 11th day inoculation, $0.1 \mu \mathrm{g} / \mathrm{ml} \mathrm{PRP}-1$ was selected for further use.

Histological methods with H\&E, Papanicolaou and Giemsa staining were applied to examine the morphological characteristics of the non-cultured control EAC cells obtained from the peritoneal cavity of mice on days 7 and 11 of tumor growth (Figs. 3 and 4). Small erythrocytes not containing nuclei, and macrophages were observed next to EAC cells. Macrophages exhibiting phagocytosis were also observed, located mainly in close contact with EAC cells. 


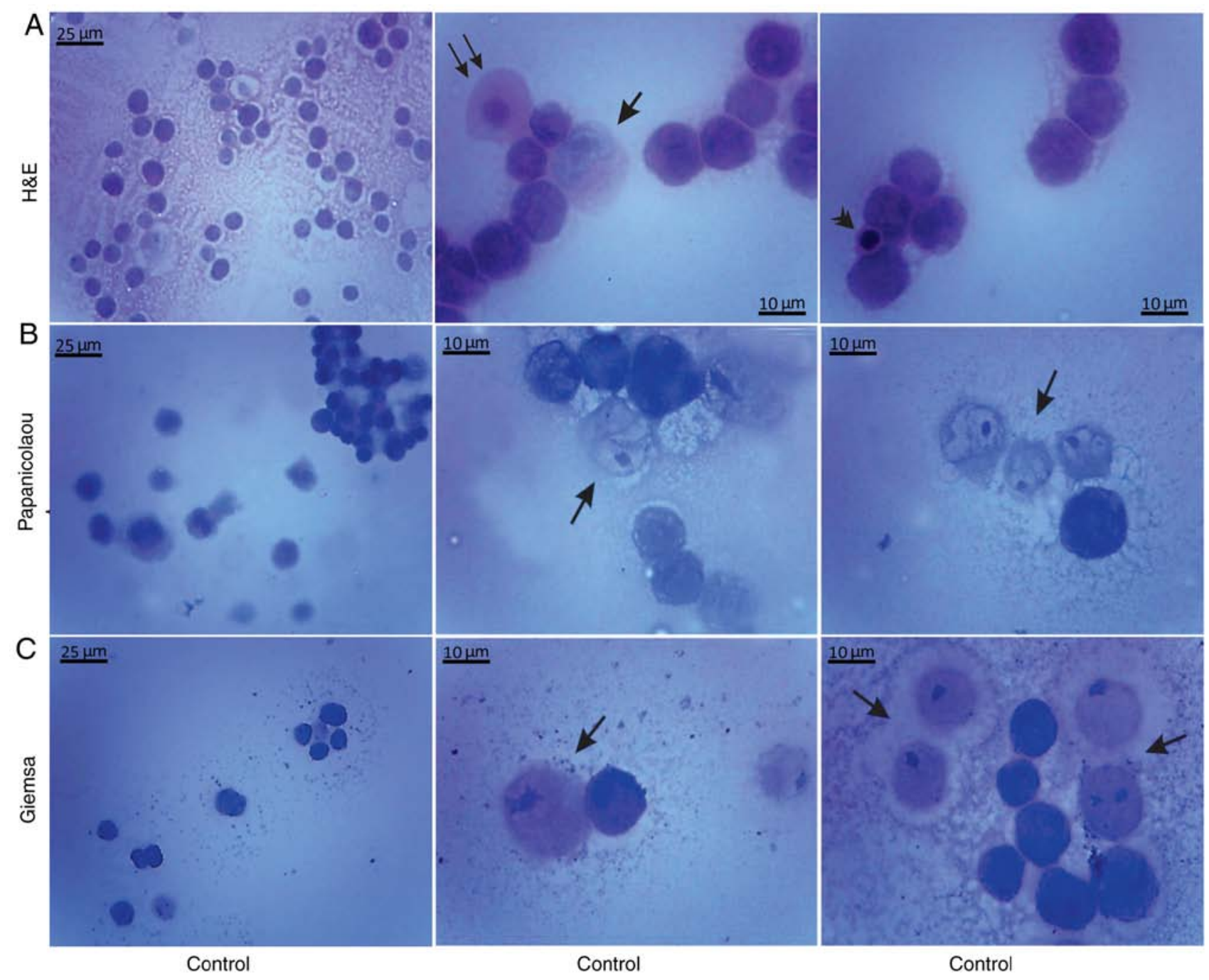

Figure 5. Morphological characteristics of isolated mice not treated with PRP-1 EAC cells on the 7th day of tumor growth before culture: Histological methods with (A) H\&E, (B) Papanicolaou and (C) Giemsa staining. (A) Control EAC cells exhibiting a typical tumor morphology, i.e. linked with each other by cytoplasmic bridges and centrally-located large nuclei in different stages of mitosis. In addition, macrophages (arrows), normoblasts (double arrows) and an apoptotic body (arrowhead) containing basophilic nuclei were observed. Cells, perhaps macrophages (arrows), weakly-stained both with (B) Papanicolaou and (C) Giemsa were located in close proximity to strongly-stained EAC cells. PRP-1, proline-rich polypeptide 1; EAC, Ehrlich ascites carcinoma; H\&E, hematoxylin and eosin.

Morphological evaluation of the isolated, by centrifugation, non-cultured control EAC cells was performed by the aforementioned histological methods on days 7 (Fig. 5) and 11 (Fig. 6) of tumor growth. The isolated control EAC cells exhibited a typical tumor morphology, i.e. linked with each other by cytoplasmic bridges, and centrally-located large nuclei in different stages of mitosis were detected. In addition, normoblasts, the apoptotic bodies, as well as macrophages were revealed, located in close proximity to strongly-stained EAC cells. Notably, EAC cells on the 11th day of tumor growth markedly differed from tumor cells on the 7th day after inoculation, since they were larger in size and exhibited pathological mitosis.

To confirm the antitumorigenic effect of PRP-1, histological examination with H\&E staining was further conducted, which is widely used in medical diagnosis and cancer detection.

PRP-1-induced morphological features of EAC cells (Figs. 7 and 8) indicated the apoptotic nature of PRP-1 as well, manifested by cell shrinkage, membrane blebbing, nuclear condensation (pyknosis) and fragmentation (karyorrhexis) as well as by a predominant presence of apoptotic bodies (30-35). There are indications that choice of program of autodestruction occurs before initiation of the irreversible phase of cell response to a lethal signal. The hallmark of apoptosis, externalization of phosphatidylserine, that designates a cell with an 'eat me' message, is the earliest feature of apoptosis triggering $(36,37)$. In necrotic cells this feature is usually registered after plasma membrane destruction; therefore, necrotizing cells are not recognized by phagocytes and they cannot be digested until their intracellular contents are spilled into the extracellular space (38). Thus, statistical analysis of the number of apoptotic and necrotic cells was based on the certain aforementioned morphological features, i.e. the nuclear lysis, activated loss of cell membrane integrity and an uncontrolled release of products of cell death into the extracellular space caused by necrosis $(39,40)$, and the cell shrinkage, membrane blebbing and predominant presence of apoptotic bodies induced by apoptosis (41). 


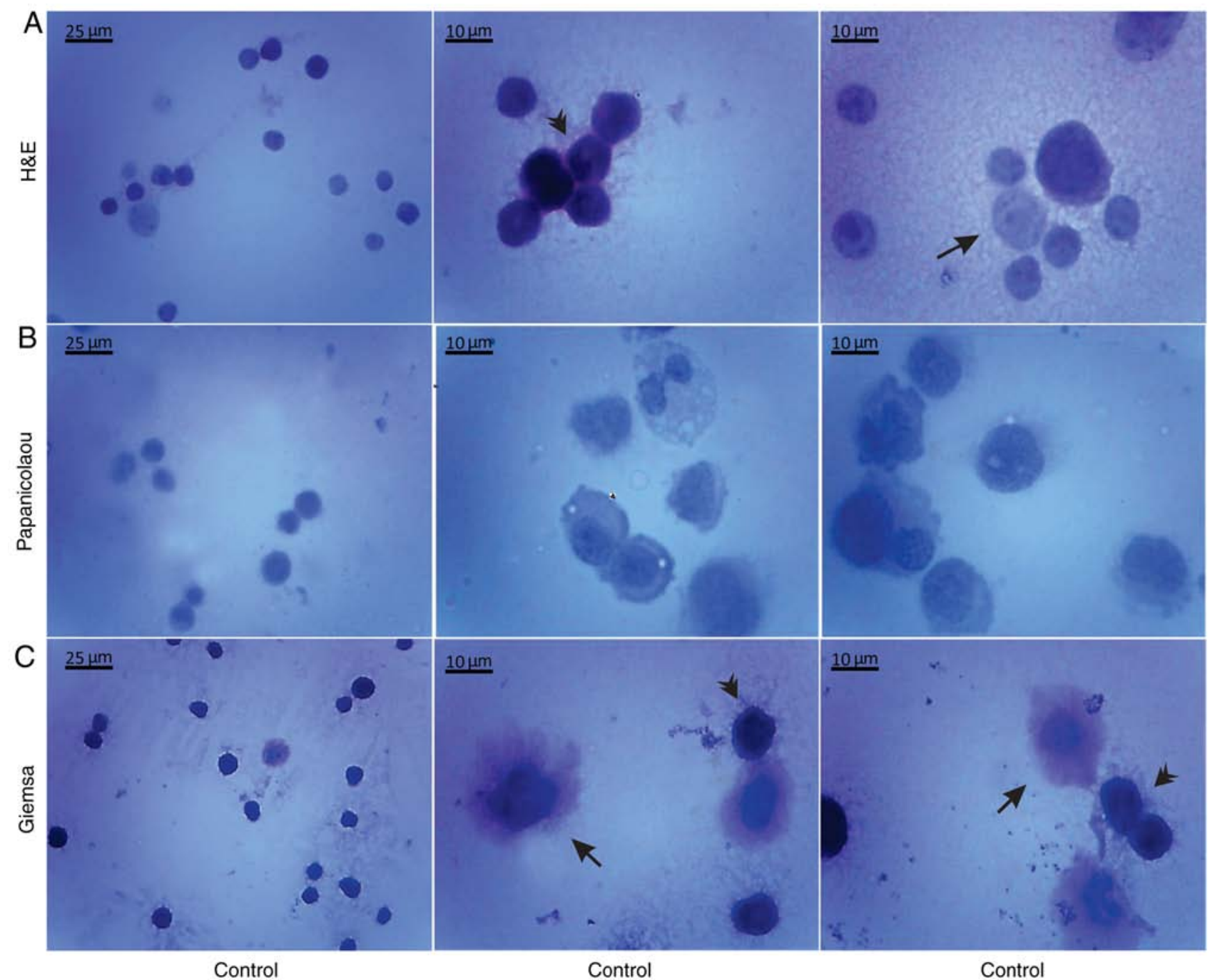

Figure 6. Morphological characteristics of isolated mice not treated with PRP-1 EAC cells on the 11th day of tumor growth before culture: Histological methods with (A) H\&E, (B) Papanicolaou and (C) Giemsa staining. (A) EAC control cells linked with each other by reticular bridges exhibited typical features of tumor cells (arrow heads). (B) EAC cells on the 11th day of tumor growth markedly differed from tumor cells on the 7th day after inoculation, since they were larger in size and exhibited pathological mitosis. (C) Tumor cells (arrow heads) and macrophages (arrows) were clearly distinguished by strong staining with Giemsa. PRP-1, proline-rich polypeptide 1; EAC, Ehrlich ascites carcinoma; H\&E, hematoxylin and eosin.

In the 7th day inoculated mice EAC cells, PRP-1 induced apoptosis by $70 \%(0.1 \mu \mathrm{g} / \mathrm{ml})$ and $37 \%(1 \mu \mathrm{g} / \mathrm{ml})$ at the $24 \mathrm{~h}$ culture, in comparison with the control samples $(8.7 \%)$. At the $72 \mathrm{~h}$ culture, PRP-induced apoptosis by $37.3 \%(0.1 \mu \mathrm{g} / \mathrm{ml})$ and $25.8 \%$ $(1 \mu \mathrm{g} / \mathrm{ml})$ compared to $1.4 \%$ apoptosis in the control samples (Fig. 7). In the control EAC cells of the 11th-day inoculated mice (Fig. 8), cultured for $24 \mathrm{~h}$, apoptosis was $31.2 \%$, whereas in the experimental samples of 0.1 and $1 \mu \mathrm{g} / \mathrm{ml} \mathrm{PRP}-1$, apoptosis was increased to 70.5 and $44.4 \%$, respectively. At the $72 \mathrm{~h}$ culture, apoptosis was $6.9 \%$ in the control group, against $25.2 \%$ for the $01 \mu \mathrm{g} / \mathrm{ml} \mathrm{PRP}-1$ group and 9\% for the $1 \mu \mathrm{g} / \mathrm{ml}$ PRP-1 group.

On the 7 th day post-inoculation a statistically significant increase in the number of necrotic cells was observed after the $24 \mathrm{~h} 1 \mu \mathrm{g} / \mathrm{ml}$ PRP-1 administration (20.9\%) compared to the control $(4.5 \%)$, whereas no differences were observed between the control and the $0.1-\mu \mathrm{g} / \mathrm{ml}$ PRP-1 (2.7\%) samples. The statistically significant decrease of the number of necrotic cells was observed for the $72 \mathrm{~h}$ treatment with $0.1 \mu \mathrm{g} / \mathrm{ml} \mathrm{PRP}-1$ $(17 \%)$ in comparison with both control samples $(65.8 \%)$ and cells exposed to $1 \mu \mathrm{g} / \mathrm{ml}$ PRP-1 (30.4\%).
On the 11th day post-inoculation, a statistically significant increase of the number of necrotic cells was also revealed after the $24 \mathrm{~h}(23.5 \%)$ culture with $1 \mu \mathrm{g} / \mathrm{ml}$ PRP-1 compared to those in the control samples $(1 \%)$ and experimental samples exposed to $0.1 \mu \mathrm{g} / \mathrm{ml} \mathrm{PRP}-1(0.5 \%)$. Thus, taking into account the similar data obtained in the control samples, as well as the samples treated with $1 \mu \mathrm{g} / \mathrm{ml}$ PRP-1, further experiments were carried out for the cells with $0.1 \mu \mathrm{g} / \mathrm{ml} \mathrm{PRP}-1$.

Fluorescence microscopy. The apoptosis-related morphological changes were monitored with histological methods (Tr-Bl and H\&E staining). The data of the statistical analysis observed in EAC cells treated with $0.1 \mu \mathrm{g} / \mathrm{ml}$ PRP-1 was confirmed by fluorescence microscopy with Annexin V-Cy3 staining (Figs. 9A and 10A) in comparison to non-treated control samples at $24 \mathrm{~h}$.

Statistically significant differences between the control and experimental samples in terms of PRP-1-induced apoptosis were observed in EAC cells, as depicted in Figs. 9B and 10B. It was revealed that $24 \mathrm{~h}$ of incubation with $0.1 \mu \mathrm{g} / \mathrm{ml}$ PRP-1 

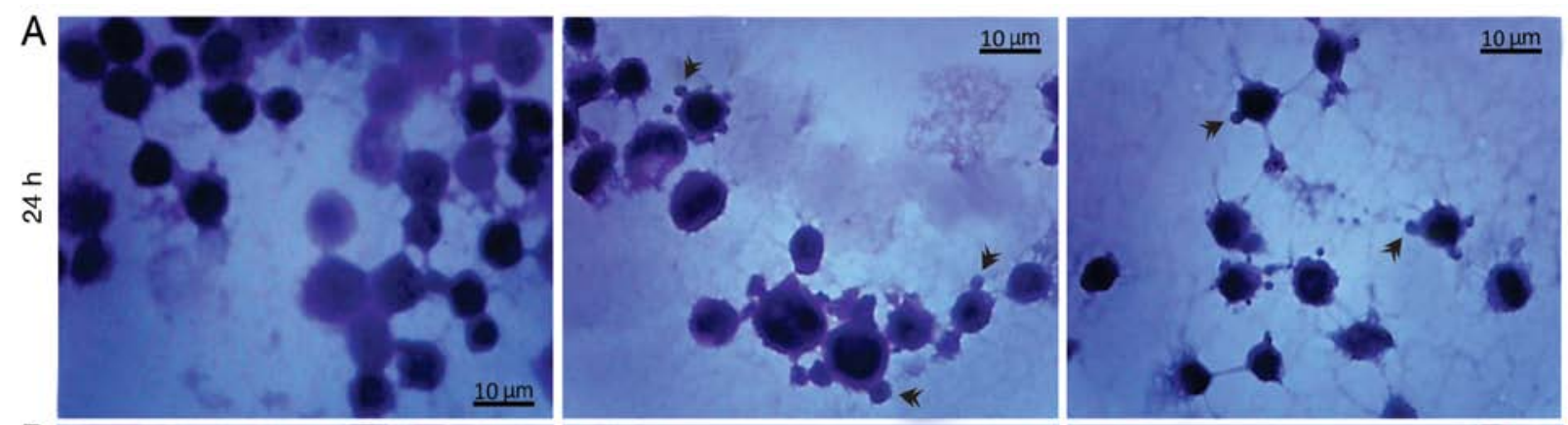

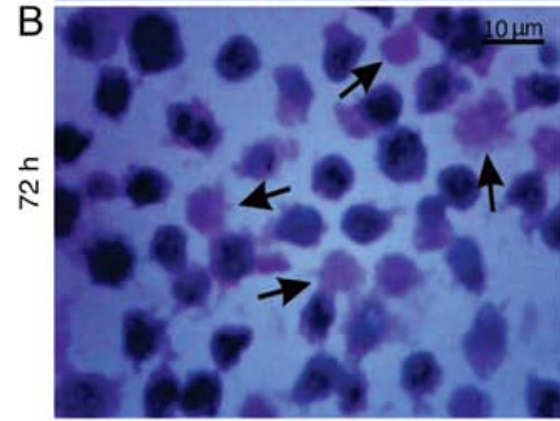

Control

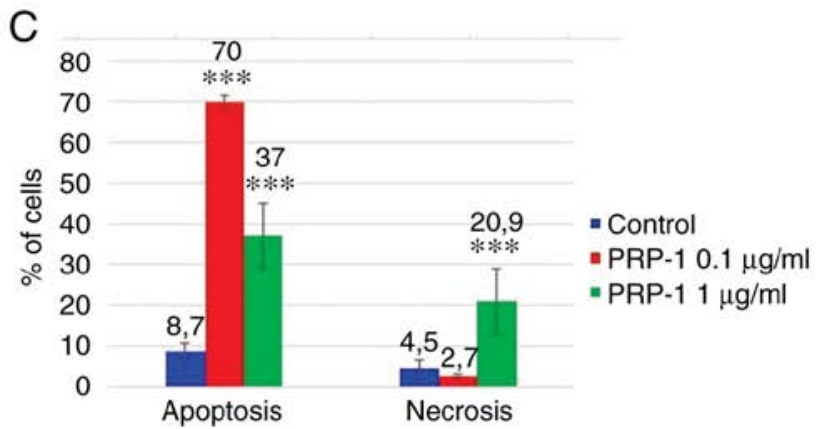

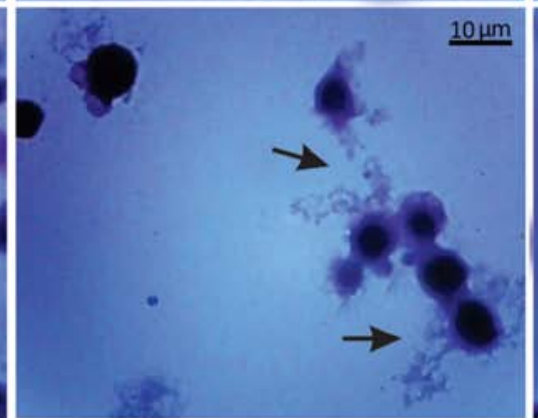

PRP-1 $0.1 \mu \mathrm{g} / \mathrm{ml}$

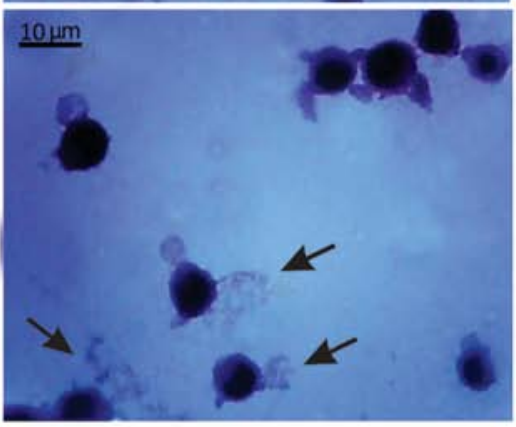

PRP-1 $1 \mu \mathrm{g} / \mathrm{ml}$

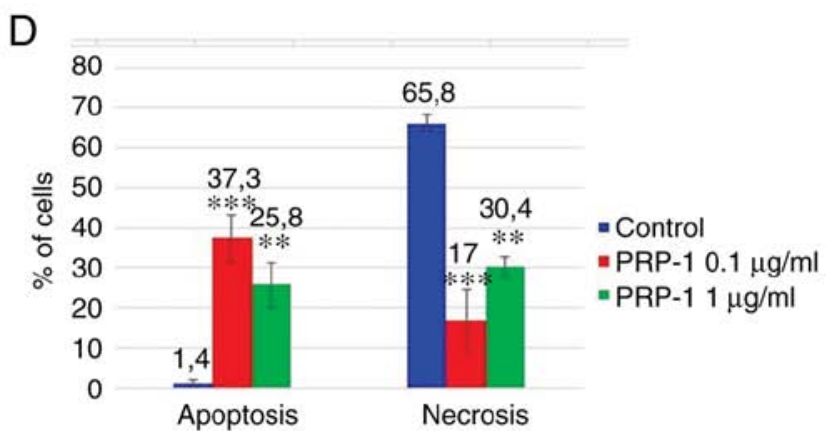

Figure 7. Histological evaluation of the hypothalamic PRP-1 effect on mouse-isolated EAC cells on day 7 of tumor growth by H\&E staining. Morphological changes of tumor cells (A) 24 and (B) $72 \mathrm{~h}$ after culture. (A) In control samples, numerous EAC cells linked with each other were detected at $24 \mathrm{~h}$, whereas a decreased number of cells was observed with both doses of PRP-1. In the experimental samples, PRP-1-induced morphological changes were similar for both the two time-points of culture. Apoptotic membrane blebbing and apoptotic bodies (arrowheads), smaller and round-shaped cells with eosinophilic cytoplasm and condensed nuclei (pyknosis), and loss of reticular extensions and contacts with adjacent cells were observed. (B) Necrotic EAC cells containing no nuclei (karyolysis) or cells with lost membrane integrity (arrows) were mainly presented in the control samples after $72 \mathrm{~h}$ of culture, whereas few necrotic cells with lost plasma membrane integrity and released cell death products (arrows) were detected in the samples treated with PRP-1 for $72 \mathrm{~h}$. Statistical data regarding the PRP-1 (0.1 and $1 \mu \mathrm{g} / \mathrm{ml})$ effect on the apoptosis and necrosis in tumor cells treated for (C) $24 \mathrm{~h}$ and (D) $72 \mathrm{~h}$ were presented according to the H\&E exclusion test in comparison with the findings in the untreated control cells. Data are presented as the mean \pm standard deviation $(\mathrm{n}=3)$, and represent $\geq 3$ independent experiments. ${ }^{* *} \mathrm{P}<0.01 ;{ }^{* * *} \mathrm{P}<0.001$, significant difference compared to (C) the control at $24 \mathrm{~h}$ and (D) the control at $72 \mathrm{~h}$. EAC, Ehrlich ascites carcinoma; PRP-1, proline-rich polypeptide $1 ; \mathrm{H} \& \mathrm{E}$, hematoxylin and eosin.

induced a statistically significant number of early apoptotic cells reaching $50.33 \%$ and late apoptotic cells $(11.33 \%)$ on day 7 post-inoculation (Fig. 9B).

According the literature data, a secondary form of necrosis has been demonstrated to occur in late apoptotic cells where apoptotic bodies undergo secondary necrotic changes and turn to detritus, taking mainly place in vitro when phagocytosis does not occur because of the absence of macrophages (38). Concomitantly, 53.34\% inhibition of the viable number of cells caused by PRP-1 was observed.

On day 11 post-inoculation, incubation with $0.1 \mu \mathrm{g} / \mathrm{ml}$ PRP-1 caused a 58\% increase in apoptotic cells and a 57.33\% decrease in viable cells (Fig. 10B).

Immunohistochemical study. Using a PRP-1-antiserum, an immunohistochemical study was carried out to detect PRP-1 localization in the EAC cells and to examine PRP-1-triggered cell death (apoptosis/necrosis) on days 7 and 11 of tumor growth (Figs. 11 and 12). The results obtained detected no PRP-1-immunoreactivity (PRP-1-IR) in the control non-cultured EAC cells. No intracellular PRP-1-IR was detected in control EAC cells as well, after $24 \mathrm{~h}$ of culture, whereas the plasma membrane exhibited weak PRP-1-IR in the form of a narrow ring. In the experimental samples, the sub-membrane cytoplasm with dense PRP-1-IR was detected in the tumor cells exposed to $0.1 \mu \mathrm{g} / \mathrm{ml}$ PRP-1. However, on the 7 and 11th days of tumor growth, at $72 \mathrm{~h}$ after EAC cell culture, nuclear, as well as dense cytoplasmatic IR for PRP-1 was detected in tumor cells both in the untreated control and PRP-1-treated samples. Morphological changes of cells undergoing death-related processes (apoptosis and necrosis) were clearly observed, including release of PRP-1-Ir intracellular 

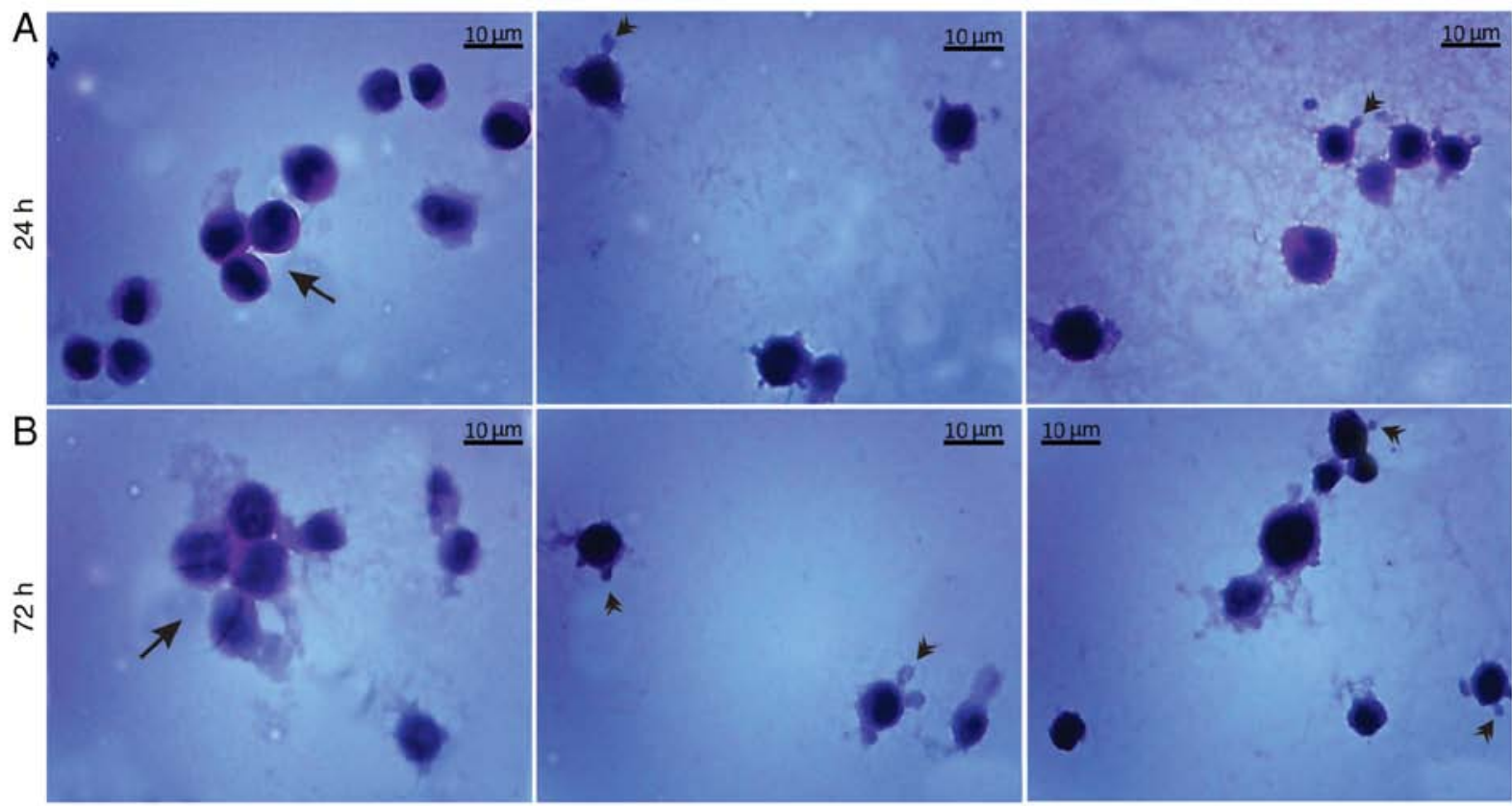

Control

PRP-1 $0.1 \mu \mathrm{g} / \mathrm{ml}$

PRP-1 $1 \mu \mathrm{g} / \mathrm{ml}$
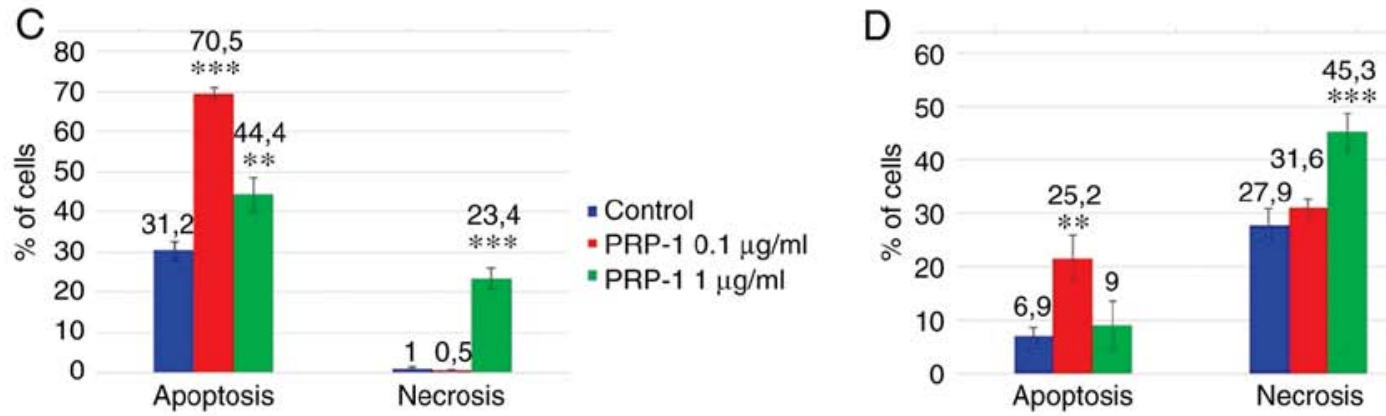

a Control

= PRP-1 $0.1 \mu \mathrm{g} / \mathrm{ml}$

= PRP-1 $1 \mu \mathrm{g} / \mathrm{ml}$

Figure 8. Histological evaluation of the hypothalamic PRP-1 effect on mouse-isolated EAC cells on the 11th day of tumor growth by H\&E staining. Morphological changes of tumor cells at (A) 24 and (B) $72 \mathrm{~h}$ after culture. In the untreated control samples, tumor cells (arrows) with typical morphology were observed after both culture time-points. In comparison to cells in the control group, cells exposed to 0.1 and $1 \mu \mathrm{g} / \mathrm{ml} \mathrm{PRP}-1 \mathrm{were}$ smaller in size and exhibited a round shape. EAC cells with the apoptotic bodies (arrowheads) were observed having no contact to adjacent cells. Statistical data regarding the PRP-1 $(0.1$ and $1 \mu \mathrm{g} / \mathrm{ml})$ effect on the apoptosis and necrosis in tumor cells treated for (C) $24 \mathrm{~h}$ and (D) $72 \mathrm{~h}$ was presented according to the H\&E exclusion test in comparison with the findings in untreated control cells. Data are presented as the mean \pm standard deviation ( $\mathrm{n}=3$ ), and represent $\geq 3$ independent experiments ${ }^{* *} \mathrm{P}<0.01 ;{ }^{* * *} \mathrm{P}<0.001$, significant difference compared to (C) the control at $24 \mathrm{~h}$ and (D) the control at $72 \mathrm{~h}$. EAC, Ehrlich ascites carcinoma; PRP-1, proline-rich polypeptide $1 ; \mathrm{H} \& \mathrm{E}$, hematoxylin and eosin.

contents from necrotic cells into the extracellular space, which was detected predominantly in the control samples, while PRP-1-immunoreactive (PRP-1-Ir) apoptotic cells with plasma blebs and apoptotic bodies were revealed mainly in the experimental samples.

Data of the statistical analysis on the PRP-1 cellular localization is presented in the Fig. 13. Thus, on the 7th day of inoculation, in the experimental samples exposed to $24 \mathrm{~h}$ $0.1 \mu \mathrm{g} / \mathrm{ml}$ PRP-1 (Fig. 13A) the sub-membrane cytoplasm with dense PRP-1-IR was detected in $46.5 \%$ of tumor cells in contrast to control cells. After $72 \mathrm{~h}$ of culture, nuclear localization of PRP-1 was detected in $\sim 4 \%$ of the control cells and in $3.3 \%$ of $0.1 \mu \mathrm{g} / \mathrm{ml}$ PRP-1-treated tumor cells. The number of cells with cytoplasmic reactivity constituted 70.4 and $73.4 \%$ in the 1 and $0.1 \mu \mathrm{g} / \mathrm{ml}$ PRP-1 groups, respectively, in contrast to $32.6 \%$ in the control cells (Fig. 13B).

On the 11th day of inoculation in the untreated control samples at $24 \mathrm{~h}$ PRP-1-IR was mainly observed in the cytoplasmic perinuclear zone in $\sim 10.1 \%$ of cells (Fig. 13C). At
$72 \mathrm{~h}$ after EAC cell culture, strong cytoplasmatic IR for PRP-1 was observed in tumor cells both in the control (48.1\%) and PRP-1-treated ( 40\%) samples (Fig. 13D).

A nuclear counterstain method with DAPI fluorescent staining applied, confirmed the immunohistochemically detected PRP-1 nuclear localization in the cultured EAC cells both in the control and $0.1 \mu \mathrm{g} / \mathrm{ml}$ PRP-1-treated samples (Fig. 14).

\section{Discussion}

The cytostatic or antiproliferative effect of the hypothalamic PRP-1 in the human chondrosarcoma JJ012 cell line was previously demonstrated after PRP-1 treatment compared with chondrocyte culture, indicating that PRP-1 selectively targets malignant sarcoma cells and not benign cells (11). Unlike in chondrosarcoma, in glioblastoma, PRP-1 does not have any inhibitory activity on cell proliferation (12). The objective of the present morphological study was to 


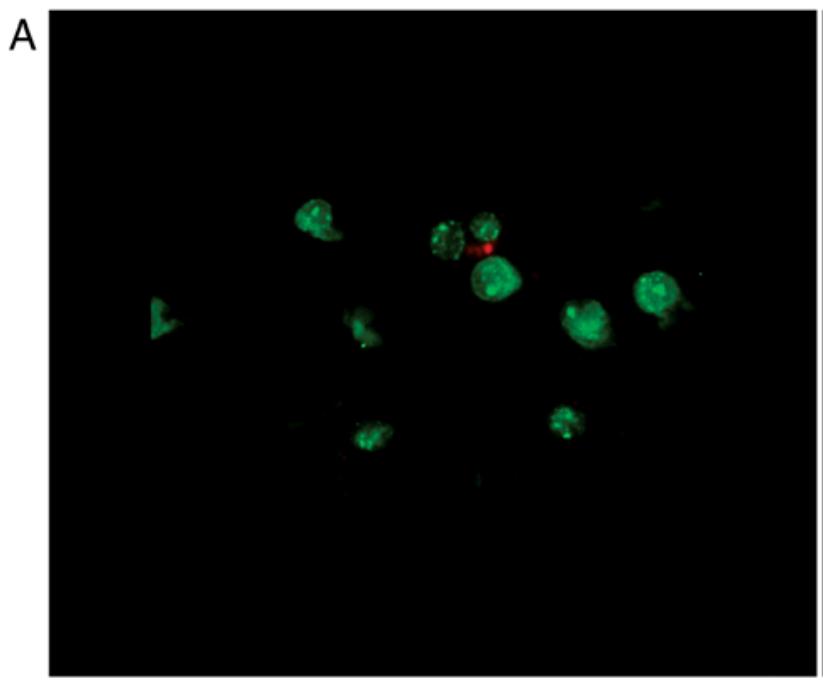

Control $(24 \mathrm{~h})$

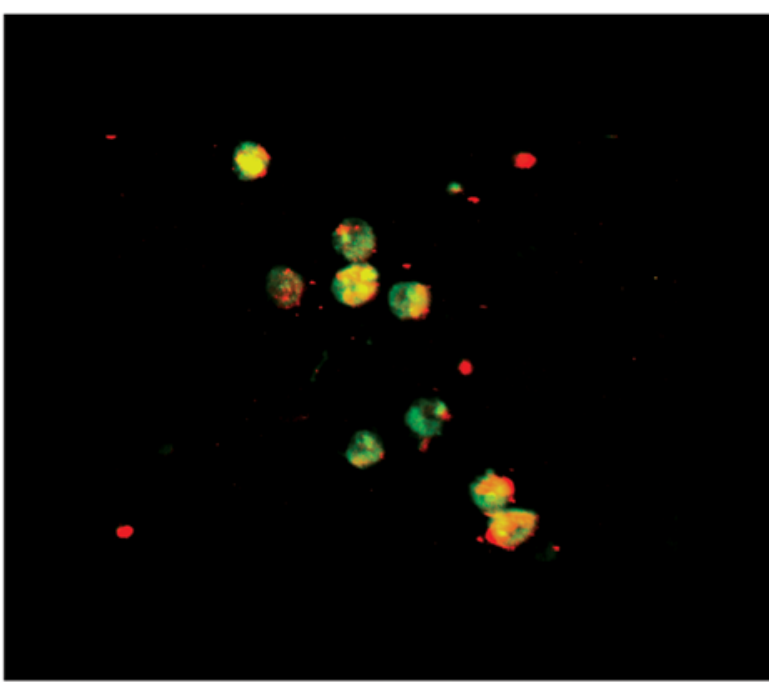

PRP-1 $0.1 \mu \mathrm{g} / \mathrm{ml}(24 \mathrm{~h})$

B

120

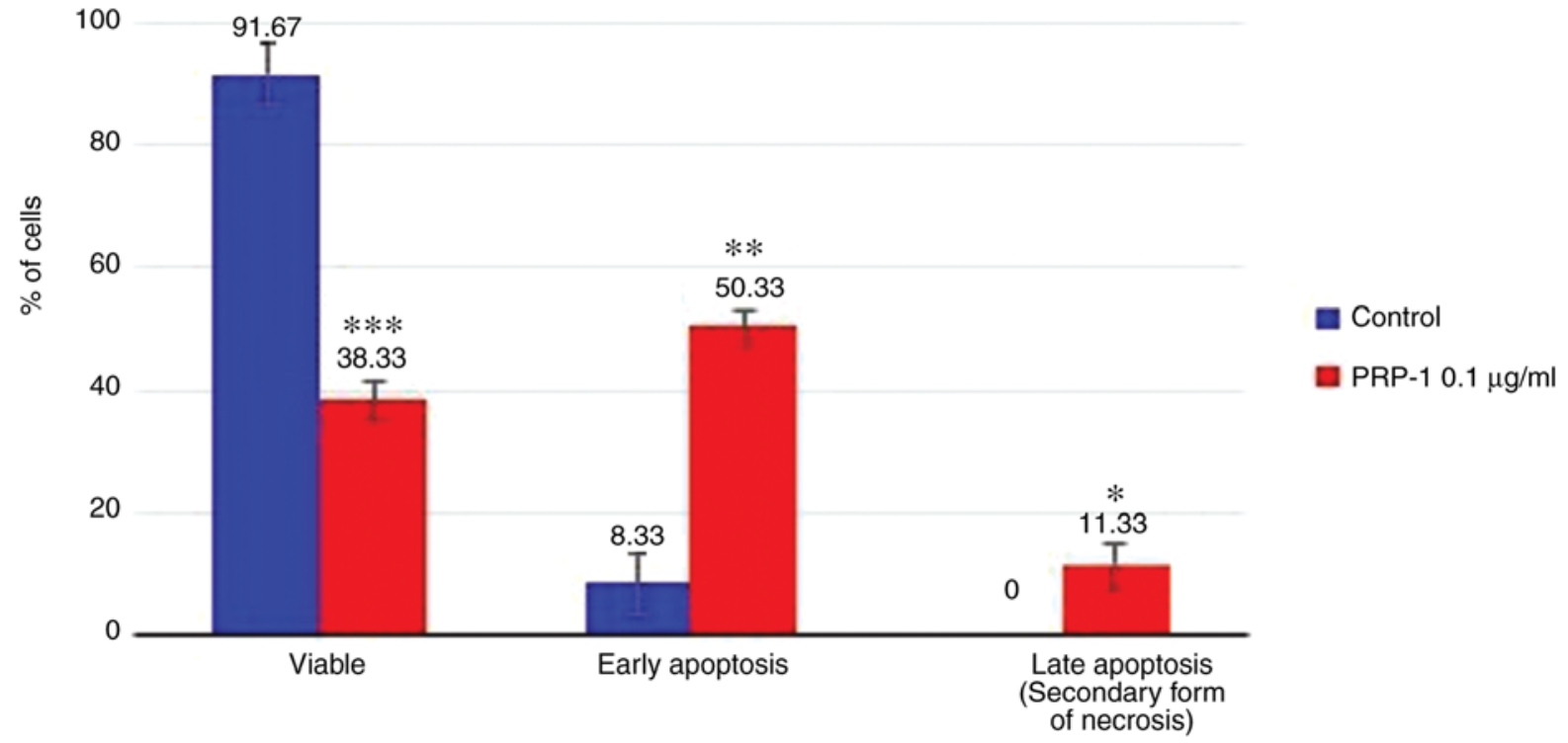

Figure 9. Analysis of apoptosis/necrosis in cultured mouse EAC cells exposed to the hypothalamic PRP-1 on the 7th day of tumor growth according to fluorescence detection with Annexin V-cyanine 3. (A) Viable EAC cultured cells (green) were detected $24 \mathrm{~h}$ after growing in the control untreated samples, although a number of necrotic nuclei (red) were also observed. In contrast to control samples, an increased number of early apoptotic cells (orange) was revealed $24 \mathrm{~h}$ after treatment with $0.1 \mu \mathrm{g} / \mathrm{ml}$ PRP-1. Fragments of necrotic nuclei (red) were clearly detected in late apoptotic cells. (B) The effect of PRP-1 on the apoptosis/necrosis of EAC cultured cells on the 7th day of tumor growth was evaluated by the Annexin V exclusion test. Statistical analysis of the data at $24 \mathrm{~h}$ clearly revealed a significant difference between the control (blue) and experimental samples (red). Treatment with $0.1 \mu \mathrm{g} / \mathrm{ml}$ PRP-1 led to a decreased number of viable cells and an increased number of early and late apoptotic cells. Data are presented as the mean \pm standard deviation $(\mathrm{n}=3$ ), and represent $\geq 3$ independent experiments. ${ }^{*} \mathrm{P}<0.05 ;{ }^{* * *} \mathrm{P}<0.01 ;{ }^{* * *} \mathrm{P}<0.001$, significant difference compared to the control at $24 \mathrm{~h}$. EAC, Ehrlich ascites carcinoma; PRP-1, proline-rich polypeptide 1 .

investigate the antitumorigenic effect of PRP-1 against EAC cells to elucidate the underlying molecular mechanisms of action (cytostatic/antiproliferative or cytotoxic/apoptotic) on the aforementioned tumor cells.

In the present study data obtained by histological method with Tr-Bl staining revealed an inhibitory effect of PRP-1 on the number of tumor cells and their viability observed $24 \mathrm{~h}$ after a single administration of PRP-1 in comparison with non-treated control samples. For example, on day 7 post-inoculation, the number of total cells was $5 \times 10^{6}$, and increased to
$8 \times 10^{6}$, with viable cells comprising $88 \%$, whereas in $0.1 \mu \mathrm{g} / \mathrm{ml}$ PRP-1-treated samples, the total number of cells decreased to $4 \times 10^{6}, 66 \%$ of which were viable cells. Thus, PRP-1 inhibited the growth of viable cells by $22 \%$. On day 11 post-inoculation, the total number of cells increased from $5 \times 10^{6}$ to $6.5 \times 10^{6}$, of which $93 \%$ were viable cells in the $24 \mathrm{~h}$ control. It is notable that there were no significant differences between the total number of EAC cells $\left(5 \times 10^{6}\right)$ exposed to 0.1 and $1 \mu \mathrm{g} / \mathrm{ml}$ PRP- 1 . As for the viable cells, in comparison with the percentage of inhibition observed in the control group, $0.1 \mu \mathrm{g} / \mathrm{ml}$ PRP-1 inhibited the 

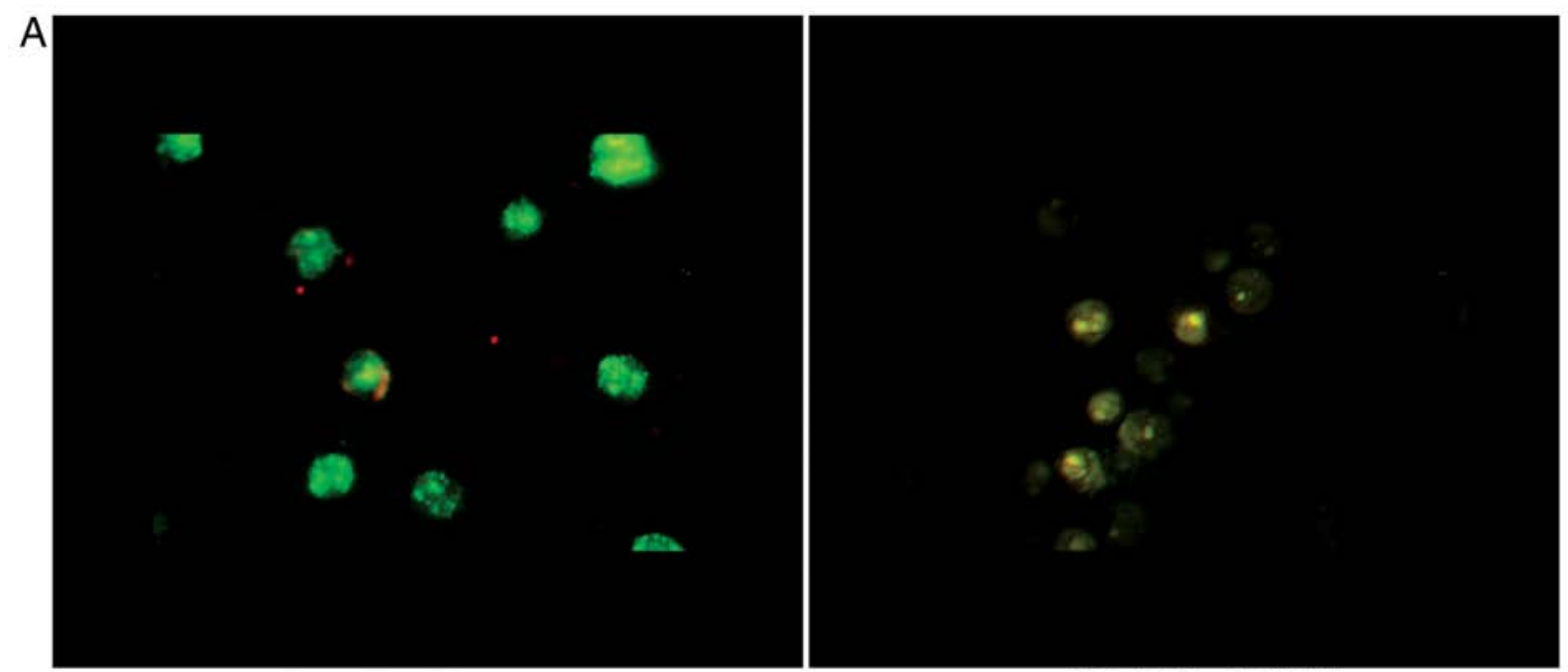

Control (24 h)

PRP-1 $0.1 \mu \mathrm{g} / \mathrm{ml}(24 \mathrm{~h})$

B

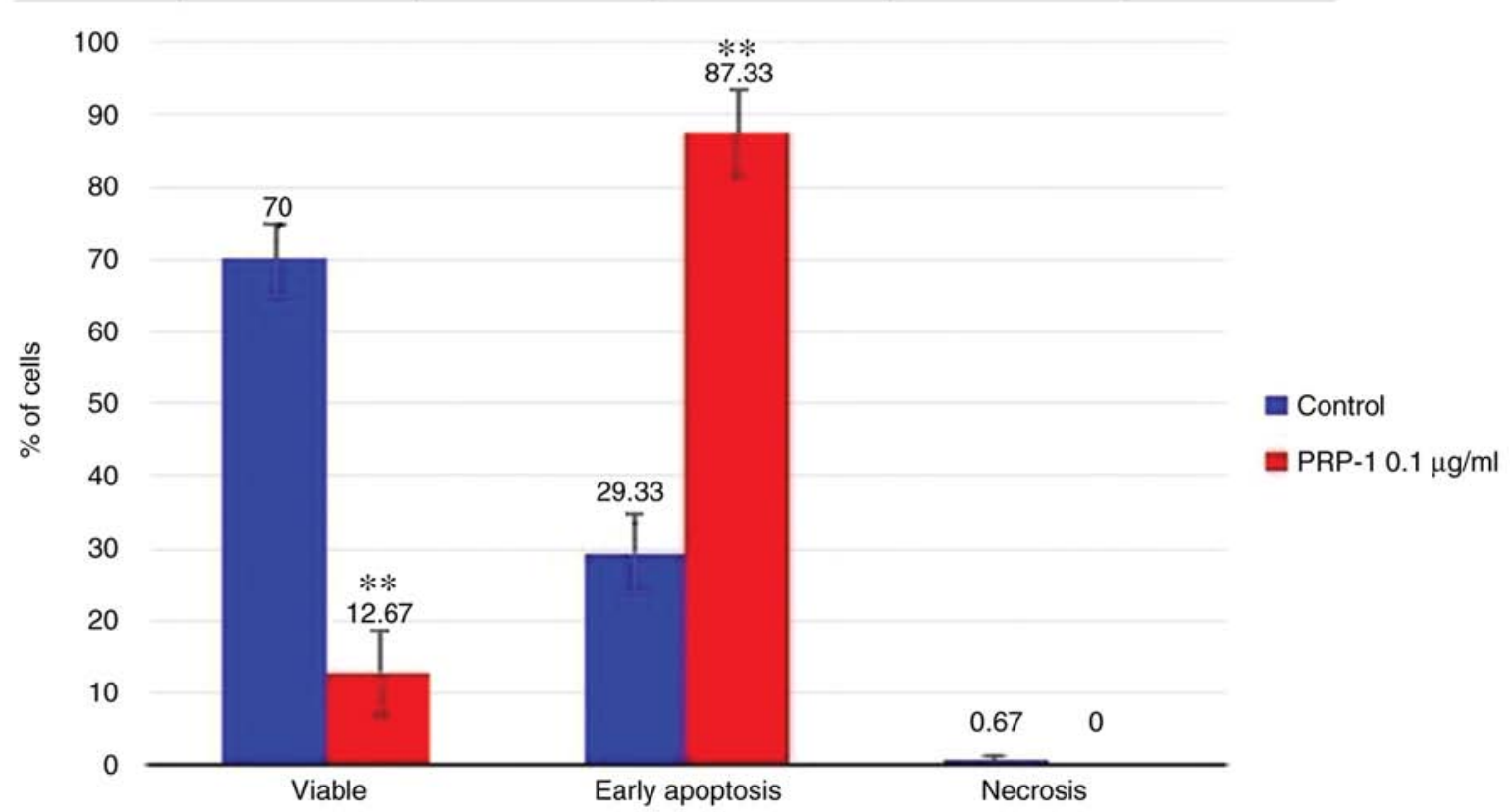

Figure 10. Analysis of apoptosis in cultured mouse EAC cells exposed to the hypothalamic PRP-1 on the 11th day of tumor growth by a fluorescence method involving Annexin V-cyanine 3 detection. (A) Viable EAC cells (green) were mainly observed in the $24 \mathrm{~h}$ control samples. After treatment with $0.1 \mu \mathrm{g} / \mathrm{ml}$ PRP-1, the plasma membrane and certain intracellular weakly-stained components could be indicative of early-stage apoptosis. (B) Effect of PRP-1 (red) on the apoptosis of cultured for $24 \mathrm{~h}$ EAC cells according to the Annexin V exclusion test. A significant increase in apoptotic cells was observed in comparison with that exhibited by the untreated control (blue). Data are presented as the mean \pm standard deviation $(\mathrm{n}=3)$, and represent $\geq 3$ independent experiments. ${ }^{* *} \mathrm{P}<0.01$, significant difference compared to the control at $24 \mathrm{~h}$. EAC, Ehrlich ascites carcinoma; PRP-1, proline-rich polypeptide 1.

viable cells by $49 \%$. The results of different types of in vitro experiments carried out by our group, such as biochemical, immunological, morphological investigations confirmed that lower doses of PRP-1 were more effective than higher doses which was distinctive of several neuropeptides (10).

Histological methods with H\&E, Papanicolaou and Giemsa staining were applied in order to examine the morphological features of the EAC control cells of mice on the 7 and 11th days of tumor growth. Staining with Papanicolaou revealed that EAC cells on the 11th day of tumor growth were markedly different from the tumor cells on the 7th day, as they were larger in size and exhibited pathological mitosis. Cells resembling macrophages were notably distinguished by strong staining with Giemsa.
Since histological methods with H\&E staining are widely used in medical diagnosis and cancer detection, H\&E staining was selected to study the morphological features of the control and PRP-1-exposed EAC cells, and to elucidate the underlying mechanisms of PRP-1 antitumor activity.

Based on the data regarding the cell shrinkage, membrane blebbing, chromosome condensation (pyknosis), nuclear fragmentation (karyorrhexis), as well as a predominant presence of apoptotic bodies (30-35), the apoptotic nature of PRP-1 was confirmed.

Conventional screening models for anticancer agents are geared toward the selection of cytotoxic drugs. It is highly desirable to have compounds that can cause cancer cell death via apoptosis, whereas the importance of cytostatic drugs, 


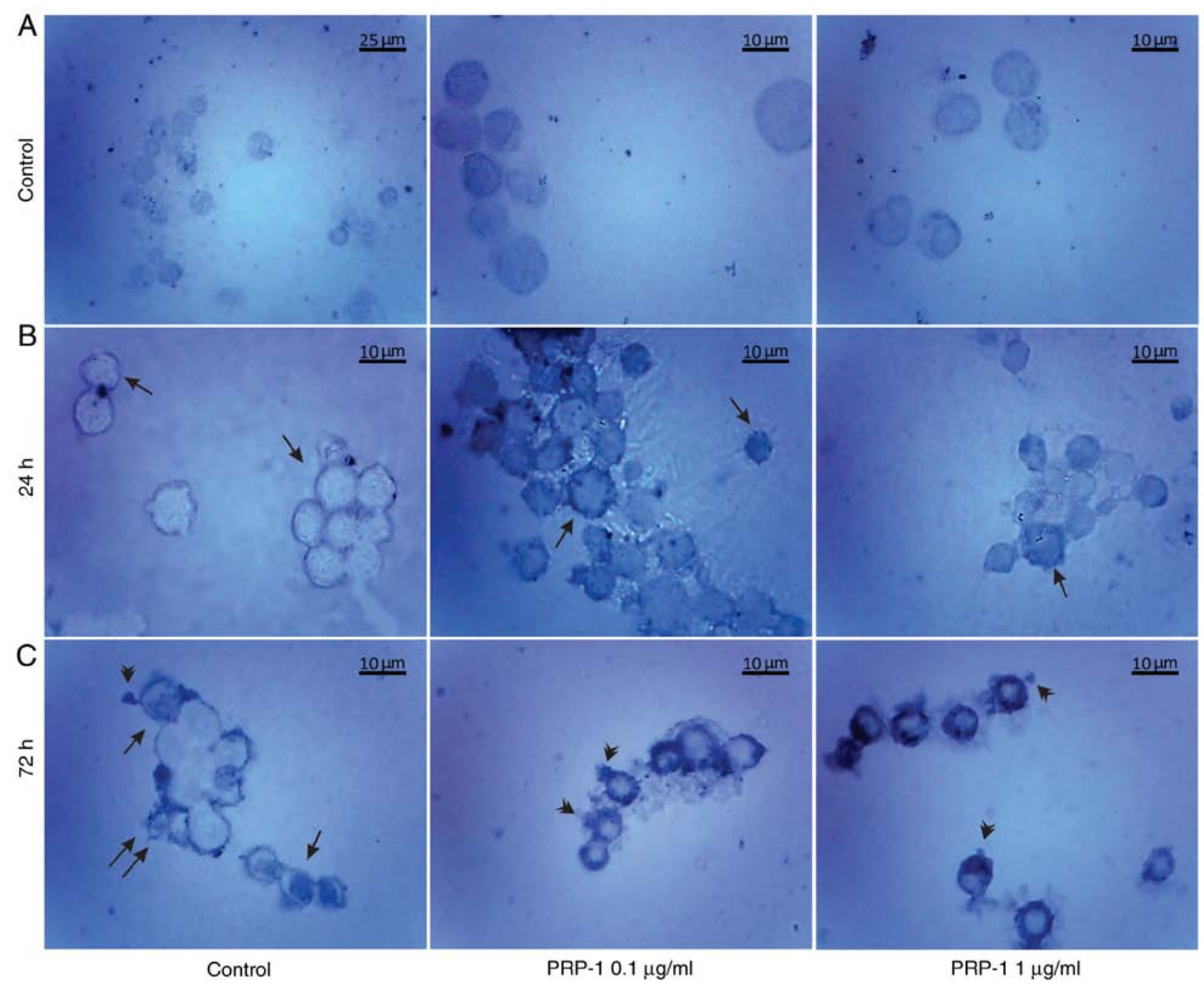

Figure 11. Immunohistochemical localization of the hypothalamic PRP-1 in cultured mouse EAC cells on the 7th day of tumor growth according to the ABC immunohistochemical method. (A) All microimages demonstrated no PRP-1-IR in EAC cells before culture (control). PRP-1-IR in tumor cells (B) at 24 h and (C) $72 \mathrm{~h}$ after culture. (B) No intracellular PRP-1-IR was detected in control EAC cells after $24 \mathrm{~h}$ of culture, whereas the plasma membrane exhibited weak PRP-1-IR in the form of a narrow ring (arrows). In experimental samples, the sub-membrane cytoplasm with dense PRP-1-IR was detected in the tumor cells (arrows) exposed to $0.1 \mu \mathrm{g} / \mathrm{ml} \mathrm{PRP-1.} \mathrm{(C)} \mathrm{After} 72 \mathrm{~h}$ of culture, nuclear localization of PRP-1 was detected in certain control (arrows) and PRP-1-treated (not shown) tumor cells. PRP-1-Ir cytoplasm was released from necrotic control cells with lost membrane integrity (double arrows). The strong PRP-1-Ir cytoplasm was revealed both in control (not demonstrated) and exposed to PRP-1 EAC cells. Notably, the apoptotic cells with the apopototic bodies (arrowheads) also demonstrated strong PRP-1-Ir cytoplasm. PRP-1, proline-rich polypeptide 1; EAC, Ehrlich ascites carcinoma; ABC, avidin-biotin complex; PRP-1-IR, PRP-1-immunoreactivity; PRP-1-Ir, PRP-1-immunoreactive.

particularly mTORC1 inhibitors, cannot be denied. In contrast to apoptosis, the membrane integrity is lost due to necrotic cellular death, accompanied by an uncontrolled release of products of cell death into the extracellular space (39-41). Data of the statistical analysis on the number of necrotic and apoptotic cells were included in the present study.

Typical morphological features of apoptotic cells can be observed using inverted phase contrast and fluorescence microscopy. In the present study, morphological data from the detection of apoptotic tumor cells indicated the apoptotic nature of PRP-1 in EAC cells. To verify this observation, a series of experiments were performed which focused on the determination of apoptosis in cultured tumor cells using an Annexin V-Cy3 apoptosis detection kit. Analysis of apoptosis by the Annexin V-Cy3 in the 7 day inoculated mice EAC-cultured cells exposed to $0.1 \mu \mathrm{g} / \mathrm{ml}$ hypothalamic PRP-1 for $24 \mathrm{~h}$ revealed early apoptotic cells, as well as late apoptotic cells, containing and surrounded by fragments of necrotic nuclei, in contrast to the numerous viable tumor cells detected in the untreated control samples. A secondary form of necrosis is known to occur in late apoptotic cells where apoptotic bodies undergo secondary necrotic changes and turn to detritus, taking mainly place in vitro when phagocytosis does not occur due to the absence of macrophages (38).

On day 11 of tumor growth after treatment with PRP-1, the cell plasma membrane and certain intracellular components manifested signs of early-stage apoptosis. Thus, the apoptotic effect of PRP-1 on EAC-cultured cells of the 7 day inoculated mice revealed a significant difference between the control and experimental samples, since PRP-1 induced a decrease in viable number of cells, and an increase the early and late apoptotic number of cells.

Apoptosis experiments indicated that $24 \mathrm{~h}$ of culture with PRP-1 induced a statistically significant increase in the 


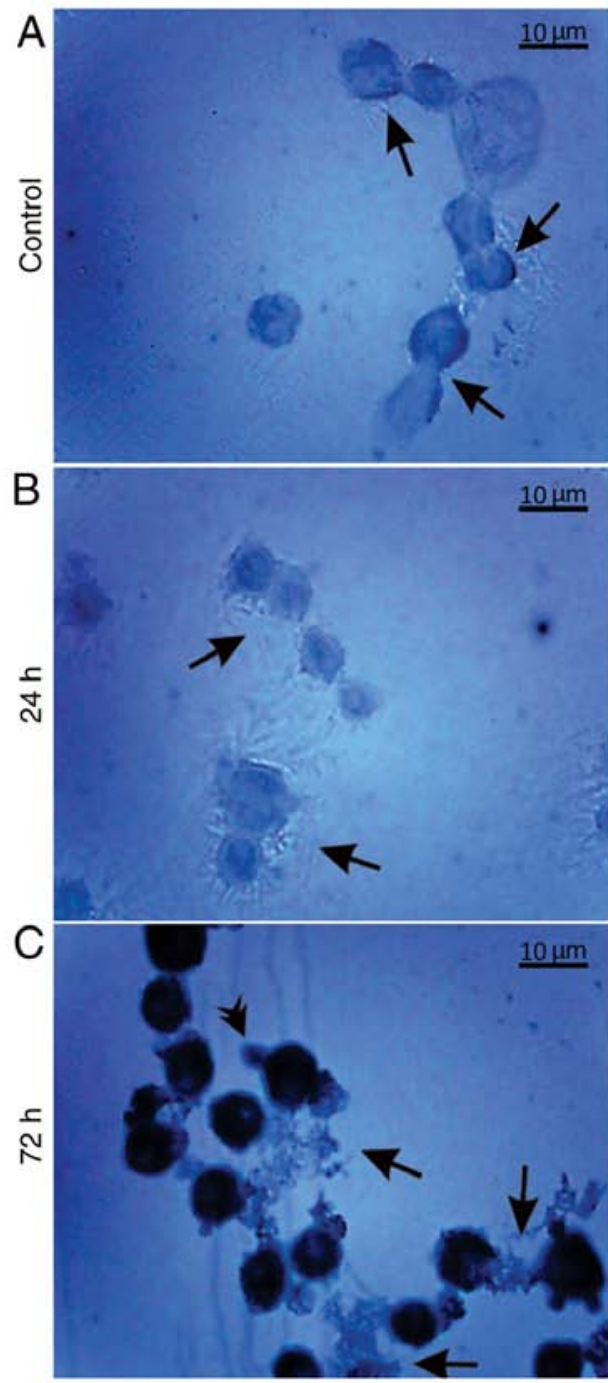

Control
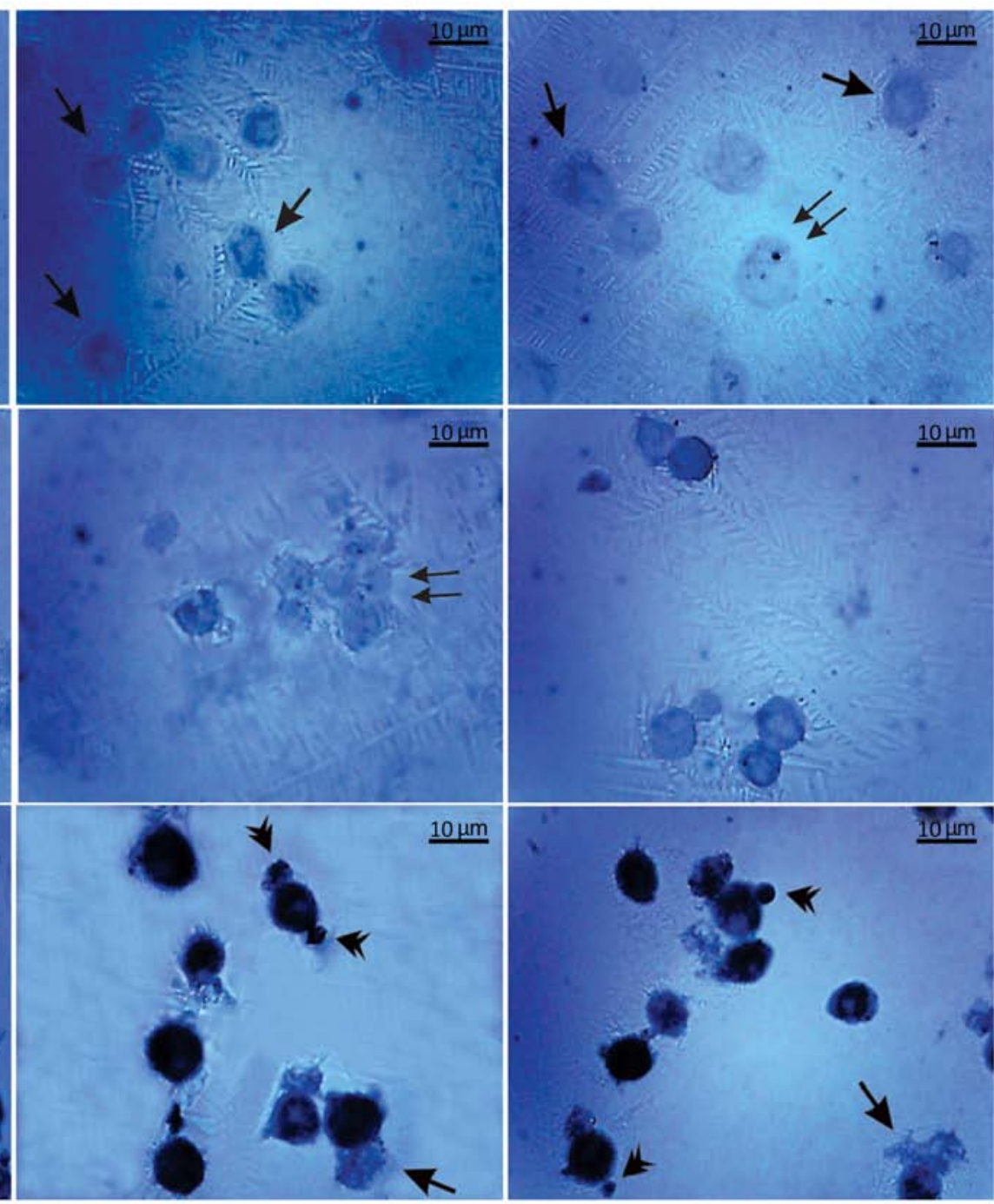

PRP-1 $0.1 \mu \mathrm{g} / \mathrm{ml}$

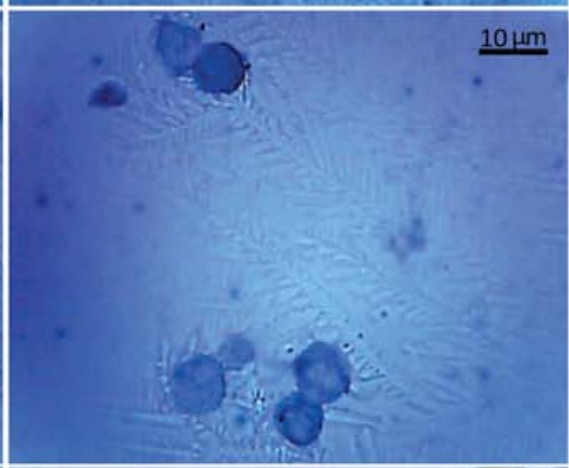

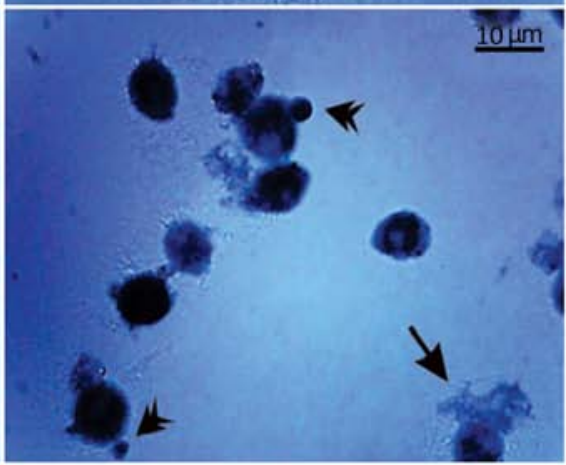

PRP-1 $1 \mu \mathrm{g} / \mathrm{ml}$

Figure 12. Immunohistochemical localization of the hypothalamic PRP-1 in cultured mouse EAC cells on the 11th day of tumor growth according to the ABC immunohistochemical method. (A) EAC control cells before culture, where PRP-1 was localized in the cell membrane, cytoplasm (arrows) and nucleoli (double arrows) of certain tumor cells. PRP-1-IR in the tumor cells (B) $24 \mathrm{~h}$ and (C) $72 \mathrm{~h}$ after their culture. (B) In the untreated control samples at $24 \mathrm{~h}$, weak PRP-1-IR was mainly observed in the perinuclear zone of cell cytoplasm. In the experimental samples exposed to $0.1 \mu \mathrm{g} / \mathrm{ml} \mathrm{PRP-1} \mathrm{for} 24 \mathrm{~h}$, PRP-1-IR was observed in the cells nucleoli (double arrows). (C) At $72 \mathrm{~h}$ after EAC cell culture, dense cytoplasmatic IR for PRP-1 was detected in tumor cells both in the control and PRP-1-treated samples. Morphological changes of cells undergoing death-related processes (apoptosis and necrosis) were clearly observed, including release of PRP-1-Ir intracellular contents from necrotic cells into the extracellular space, which was detected predominantly in the control samples (arrows), while PRP-1-Ir plasma blebs and apoptotic bodies (arrowheads) were revealed mainly in the experimental samples. PRP-1, proline-rich polypeptide 1; EAC, Ehrlich ascites carcinoma; ABC, avidin-biotin complex; PRP-1-IR, PRP-1-immunoreactivity; PRP-1-Ir, PRP-1-immunoreactive.

number of early apoptotic cells, reaching $50.33 \%$ on day 7 post-inoculation, whereas day 11 post-inoculation, a $58.33 \%$ increase in the number of early apoptotic cells was detected. In conclusion, the PRP-1 effect was cellular-context dependent, and in EAC cells acted as a cytotoxic agent, causing programmed cell death type I apoptosis.

A series of experiments which aimed to elucidate the possible participation of PRP-1 in antitumorigenic processes were carried out by detecting the immunohistochemical localization of PRP-1 in the control and experimental EAC cells using an antibody against the synthetic hypothalamic polypeptide of interest.

On the 7th day of tumor growth, no PRP-1-IR was detected in the mice non-cultured control EAC cells. In the untreated control EAC cells cultured for $24 \mathrm{~h}$, no intracellular PRP-1-IR was detected, but the PRP-1-Ir cell membrane (21\%) was demonstrated in the form of a narrow ring. In the experimental samples exposed to $0.1 \mu \mathrm{g} / \mathrm{ml}$ PRP-1, strong PRP-1-IR was observed in the cytoplasm $(46.5 \%)$ and nucleoli (10\%) of the total number of tumor cells.

In the control cells, as well as in the PRP-1-treated samples after $72 \mathrm{~h}$ of incubation, nuclear localization of PRP-1 was detected in 3.3-4\% of tumor cells, which was statistically not significant. However, the number of cells exposed to PRP-1 with cytoplasmic PRP-1-IR constituted 73.4\%, in contrast to $32.6 \%$ of the control cells. Notably, dense PRP-1-IR was noticed in $25 \%$ of apoptotic cells with the membrane blebbing, in contrast to $4 \%$ of the untreated control cells.

Immunohistochemically-detected PRP-1 nuclear localization in the cultured EAC cells both in the control and 


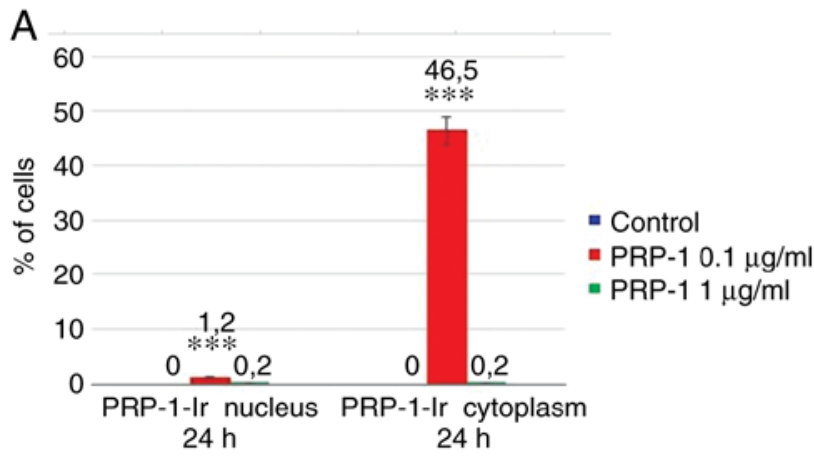

C

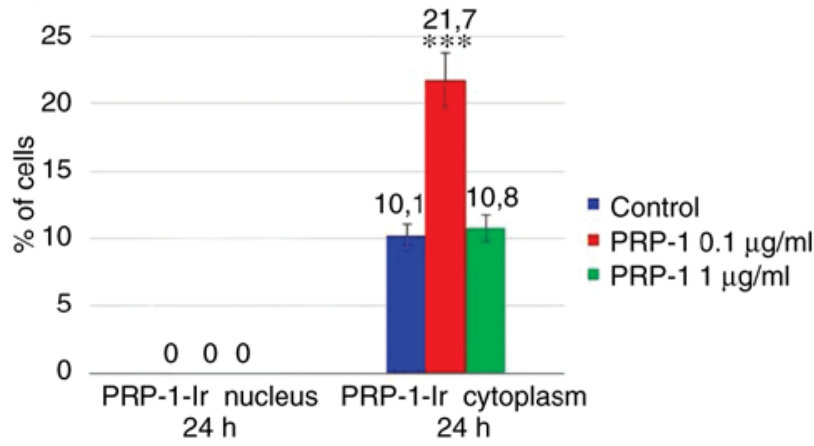

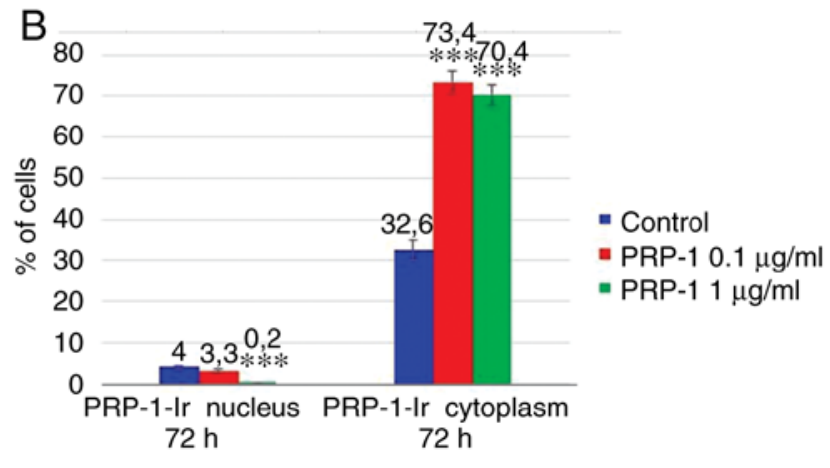

D

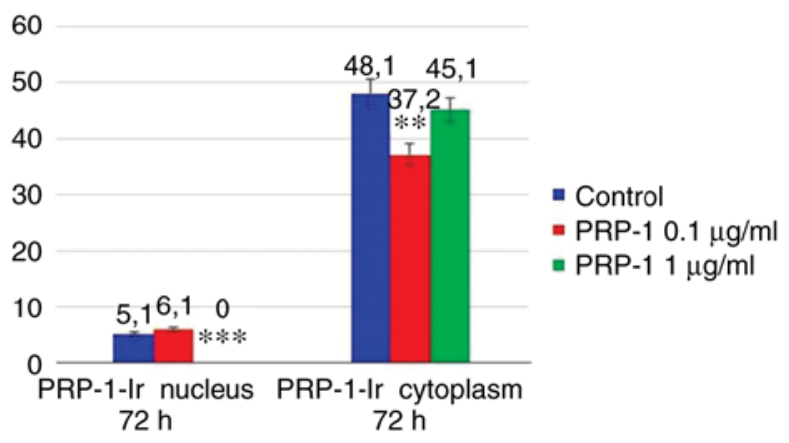

Figure 13. Statistical data regarding the PRP-1 localization in the cultured (A and C) $24 \mathrm{~h}$ and (B and D) $72 \mathrm{~h}$ control, 0.1 and $1 \mu \mathrm{g} / \mathrm{ml} \mathrm{PRP-1-treated} \mathrm{cells} \mathrm{of}$ days 7 and 11 of tumor growth in mice are presented according to the immunohistochemical exclusion test. Data are presented as the mean \pm standard deviation $(\mathrm{n}=3)$, and represent $\geq 3$ independent experiments. ${ }^{* *} \mathrm{P}<0.01$ and ${ }^{* * *} \mathrm{P}<0.001$, significant difference compared to (A and C) the control at $24 \mathrm{~h}$ and (B and D) the control at $72 \mathrm{~h}$. PRP-1, proline-rich polypeptide 1; PRP-1-Ir, PRP-1-immunoreactive.
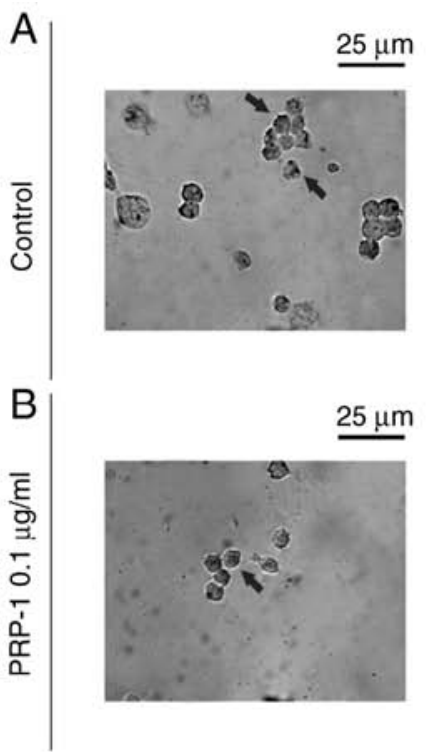

$\mathrm{IHC}$
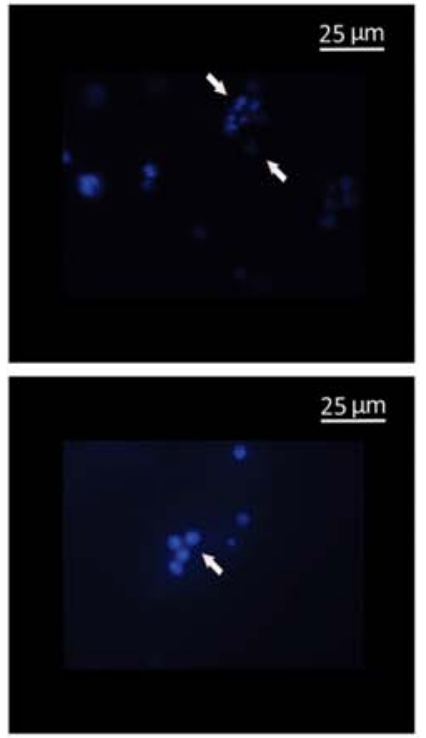

DAPI
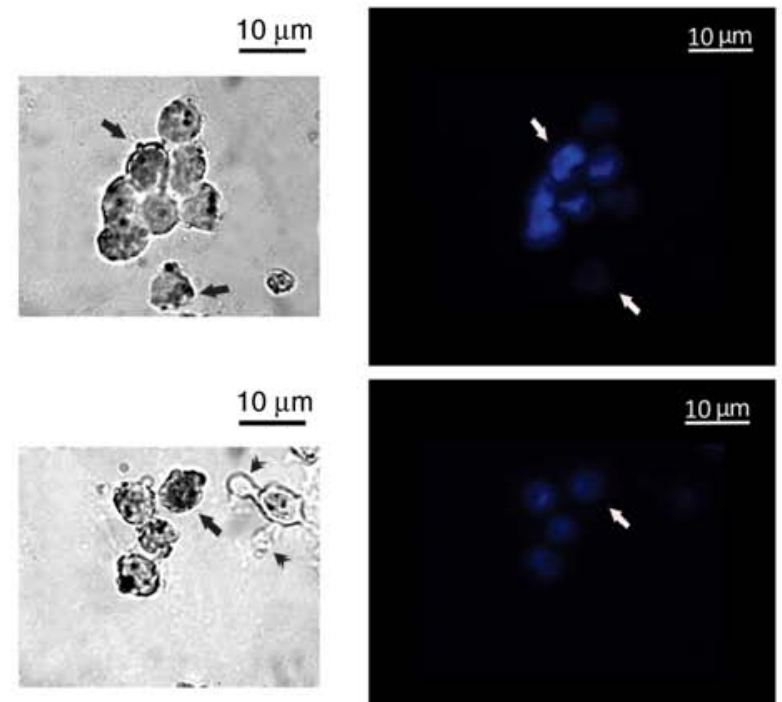

$\mathrm{IHC}$

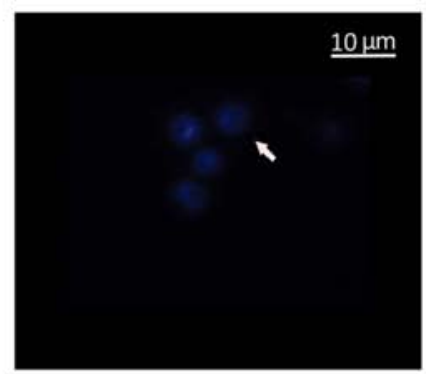

DAPI

Figure 14. Detection of the nuclei in the mouse EAC-cultured cells according to the ABC immunohistochemical method and nuclear counterstain method with DAPI fluorescent dye. Seventy-two hours after EAC cell culture, PRP-1-Ir nuclei (arrows) were detected in the (A) control and (B) $0.1 \mu \mathrm{g} / \mathrm{ml}$ PRP-1-treated tumor cells; an apoptotic tumor cell with the isolated apoptotic bodies is well demonstrated (arrowheads). DAPI counterstained nuclei (arrows) in the (A) control and (B) $0.1 \mu \mathrm{g} / \mathrm{ml}$ PRP-1-treated tumor cells were revealed. EAC, Ehrlich ascites carcinoma; ABC, avidin-biotin complex; PRP-1-Ir, PRP-1-immunoreactive; PRP-1, proline-rich polypeptide 1; DAPI, 4',6-diamidino-2-phenylindole.

PRP-1-treated samples was confirmed by the nuclear counterstain method with DAPI fluorescent staining.In mice inoculated for 11 days, PRP-1-IR was different in control-EAC cells before their culture compared with that of cells after 7 days of tumor growth. In certain EAC cells, weak positivity for PRP-1 was observed in the cell membrane (15\%) and the perinuclear zone of the cytoplasm (9\%). In the experimental samples exposed to $0.1 \mu \mathrm{g} / \mathrm{ml} \mathrm{PRP}-1$ for $24 \mathrm{~h}$, PRP-1-IR was observed 
in the nucleoli of the cultured tumor cells. Morphological changes of cells undergoing death-related processes (apoptosis and necrosis) were clearly observed $72 \mathrm{~h}$ after EAC cell culture, as manifested by markedly dense cytoplasmatic IR for PRP-1 both in the control (48\%) and PRP-1-treated ( 40\%) samples. PRP-1-Ir cell membrane blebs and apoptotic bodies were observed in close contact to EAC cells mainly in the experimental samples, indicating that apoptosis was involved in the underlying mechanisms of PRP-1 antitumorigenic action. PRP-1-IR was detected in the nucleus and cytoplasm of EAC cells cultured for $72 \mathrm{~h}$ in both control (untreated) and exiperimental (PRP-1-treated) samples, which may be explained by the possible biosynthesis of endogenous PRP-1 in the studied cancer cells. This hypothesis is in agreement with previous immunohistochemical data on the detection of PRP-1 in the nuclei of neural cells of labyrinthectomized rats (42), motoneurons of spinal cord hemisectioned rats in response to cobra venom administration (43) and bone marrow-derived immune system cells of immobilized rats (44).

The time-dependent quantity of PRP-1 expression in the blood samples of PRP-1-injected rats was demonstrated previously (45). Thus, PRP-1 has been quantified in intact (normal) rat blood serum samples, which was estimated to be $\sim 1.78 \mathrm{ng} / \mathrm{ml}$, with a significant increase in PRP-1 concentration $(36.76 \mathrm{ng} / \mathrm{ml})$ in blood samples at $5 \mathrm{~h}$ post-PRP-1 i/p injection. However, the peptide concentration in the blood decreased at day 2 post-injection to $3.111 \mathrm{ng} / \mathrm{ml}$, similar to that found in the control, which was explained by proteolytic breakdown of the peptide. This assumption has been based on the recently revealed data indicating PRP-1 as a new natural substrate for DPPs (46) that are widely expressed on the surface of the lymphocytes in the blood plasma, substrates of which are chemokines, hormones, neuropeptides, and growth factors $(47,48)$.

In summary, the present immunohistochemical results revealed PRP-1 localization in the nucleus and cytoplasm of both untreated control and PRP-1-exposed experimental EAC cells cultured for $72 \mathrm{~h}$, which can be indicative of endogenous PRP-1 synthesis. Notably, our group previously reported the detection of PRP-1 receptors in the nuclei of cancer cells (15). Further in vitro and in vivo experiments are required to identify the involvement of particular caspases in apoptosis and to elucidate other PRP-1-triggered molecular pathways leading to cancer cell death.

\section{Acknowledgements}

Authors would like to thank the Miami Center of Orthopaedic Research and Education (Miami, FL, USA). Ehrlich Ascites Carcinoma (EAC) cells were kindly provided by Senior Researcher Hrachya Stepanyan from the laboratory of Toxicology and Experimental Chemotherapy, Institute of Fine Organic Chemistry, NAS, Armenia.

\section{Funding}

The present study was supported in part by a gift from Ratcliffe Foundation to the Miami Center of Orthopaedic Research and Education and the Buniatian Institute of Biochemistry NAS of the Republic of Armenia.

\section{Availability of data and materials}

All data generated or analyzed during this study are included in this published article.

\section{Authors' contributions}

SA, IS, NT, NK, TD and KG were involved in the study design and contributed to the preparation of the manuscript and data analysis. AS and RA were in charge of the fluorescence microscopy, statistical and experimental data analysis at Yerevan State University. GC and SC contributed to the peptide synthesis. All authors read and approved the final manuscript and agree to be accountable for all aspects of the research in ensuring that the accuracy or integrity of any part of the work are appropriately investigated and resolved.

\section{Ethics approval and consent to participate}

The Institutional Animal Ethics Committee of the Institute of Biochemistry after H.Buniatian, NAS, RA (IRB 0001621; IORG0009782) provided approval for the use of the animals in the present study.

\section{Patient consent for publication}

Not applicable

\section{Competing interests}

The authors declare that they have no competing interests.

\section{References}

1. Galoyan A: Neurochemistry of brain neuroendocrine immune system: Signal molecules. Neurochem Res 25: 9-10, 2000.

2. Markossian KA, Gurvitz BY and Galoyan AA: Isolation and chemical identification of new peptides from neurosecretory granules of hypothalamus. Neurokhimiya 16: 22-25, 1999.

3. Davtyan TK, Manukyan HA, Mkrtchyan NR, Avetisyan SA and Galoyan AA: Hypothalamic proline-rich polypeptide is a regulator of oxidative burst in human neutrophils and monocyte. Neuroimmunomodulation 12: 270-284, 2005.

4. Galoyan AA, Sarkissian JS, Sulkhanyan RM, Chavushyan VA, Avetisyan ZA, Avakyan ZE, Gevorgyan AJ, Abrahamyan DO and Grigorian YKh: PRP-1 protective effect against central and peripheral neurodegeneration following $\mathrm{n}$. ischiadicus transection. Neurochem Res 30: 487-505, 2005.

5. Galoian K, Luo S, Qureshi A, Patel P, Price R, Morse A, Chailyan G, Abrahamyan S and Temple HT: Proline rich polypeptide-1 and inflammatory pathway signaling in chondrosarcoma. Mol Clin Oncol 5: 618-624, 2016.

6. Durgaryan AA, Matevosyan MB, Seferyan TY, Sargsyan MA, Grigoryan SL, Galoian KA and Galoyan AA: The protective and immunomodulatory effects of hypothalamic proline-rich polypeptide galarmin against methicillin-resistant Staphylococcus aureus infection in mice. Eur J Clin Microbiol Infect Dis 3: 2153-2165, 2012.

7. Galoyan AA, Korochkin LI, Rybalkina EJ, Pavlova GV, Saburina IN, Zaraiski EI, Galoyan NA, Davtyan TK, Bezirganyan KB and Revishchin AV: Hypothalamic proline-rich polypeptide enhances bone marrow colony-forming cell proliferation and stromal progenitor cell differentiation. Cell Transplant 17: 1061-1066, 2008.

8. Galoyan KA, Scully SP and Galoyan AA: Myc-Oncogene inactivating effect by proline rich polypeptide (PRP-1) in chondrosarcoma. Neurochem Res 34: 379-385, 2009. 
9. Galoian K, Temple TH and Galoyan A: Cytostatic effect of the hypothalamic cytokine PRP-1 is mediated by its inhibition of mTOR and cMyc in high grade metastatic chondrosarcoma. Neurochem Res 36: 812-818, 2011.

10. Galoian KA, Temple HT and Galoyan AA: Cytostatic effect of novel mTOR inhibitor, PRP-1 in MDA231 (ER-) breast carcinoma cell line. The cytokine inhibits mesenchymal tumors. Tumor Biol 32: 745-751, 2011.

11. Galoian KA, Guettouche T, Issac B, Qureshi A and Temple HT: Regulation of onco and tumor suppressor miRNAs by mTORC1 inhibitor PRP-1 in human chondrosarcoma. Tumour Biol 35 2335-2341, 2014.

12. Galoian K, Qureshi A, Dippolito G, Schiller PC, Molinari M, Johnstone AL, Brothers SP, Paz AC and Temple HT: Epigenetic regulation of embryonic stem cell marker miR302C in human chondrosarcoma as determinant of antiproliferative activity of proline rich polypeptide-1. Lnt J Oncol 47: 465-472, 2015.

13. Galoian K, Qureshi A, Wideroff G and Temple HT: Restoration of desmosomal junction protein expression and inhibition of H3K9-specific histone demethylase activity by cytostatic proline-rich polypeptide-1 leads to suppression of tumorigenic potential in human chondrosarcoma cells. Mol Clin Oncol 3 : 171-178, 2015.

14. Chailakhyan RK, Gerasimov YV, Chailakhyan MR and Galoyan AA: Proline-rich hypothalamic polypeptide has opposite effects on the proliferation of human normal bone marrow stromal cells and human giant-cell tumour stromal cells. Neurochem Res 35: 934-939, 2010.

15. Galoian K, Abrahamyan S, Chailyan G, Qureshi A, Patel P, Metser G, Moran A, Sahakyan I, Tumasyan N, Lee A, et al: Toll like receptors TLR1/2, TLR6 and MUC5B as binding interaction partners with cytostatic proline rich polypeptide 1 in human chondrosarcoma. Int J Oncol 52: 139-154, 2018.

16. Galoian K, Scully S, McNamara G, Flynn P and Galoyan A: Antitumorigenic effect of brain proline rich polypeptide-1 in human chondrosarcoma. Neurochem Res 34: 2117-2121, 2009.

17. Jaganathan SK, Mondhe D, Wani ZA, Pal HC and Mandal M: Effect of honey and eugenol on Ehrlich ascites and solid carcinoma. J Biomed Biotechnol: 989163, 2010.

18. Frajacomo FT, de Souza Padilha C, Marinello PC, Guarnier FA, Cecchini R, Duarte JA and Deminice R: Solid Ehrlich carcinoma reproduces functional and biological characteristics of cancer cachexia. Life Sci 162: 47-53, 2016.

19. Mondal A, Singha T, Maity TK and Pal D: Evaluation of antitumor and antioxidant activity of melothriaheterophylla (Lour.). Cogn. Indian J Pharm Sci 75: 515-522, 2013.

20. Strober W: Trypan blue exclusion test of cell viability. Curr Protoc Immunol 111: A3B1-A3B3, 2015.

21. Fischer A, Jacobson KA, Rose J and Zeller R: Hematoxylin and eosin staining of tissue and cell sections. CSH Protoc pdb. prot4986, 2008.

22. Redginal H: Giemsa preparation for staining blood films. Science 86: 548, 1937.

23. Deshpande AK, Bayya P and Veeragandham S: Comparative study of Papanicolaou stain (PAP) with rapid economic acetic acid papanicolaou stain (REAP) in cervical cytology. J Evolution of Med Dental Sci 4: 7089-7095, 2015.

24. Farinacci M: Improved apoptosis detection in ovine neutrophils by annexin $\mathrm{V}$ and carboxyfluorescein diacetate staining. Cytotechnology 54: 149-155, 2007.

25. Szkaradek N, Sypniewski D, Waszkielewicz AM Gunia-Krzyżak A, Galilejczyk A, Gałka S, Marona $\mathrm{H}$ and Bednarek I: Synthesis and in vitro evaluation of the anticancer potential of new aminoalkanol derivatives of xanthone. Anticancer Agents Med Chem 16: 1587-1604, 2016.

26. Hsu SM, Roine L and Farger H: Use of avidin-biotin-peroxidasee $(\mathrm{ABC})$ in immunoperoxidase technioques: comparison between $\mathrm{ABC}$ and unlabelled antibody (PAP) procedures. J Histochem Cytochem 29: 577-580, 1981

27. Ambrosius $\mathrm{X}$ : Obtaining of antisera from different animals. In Immunological methods. Frimel HG (ed). pp14-15, 1987.

28. Bret-Dibat JL, Zouaoui D, Déry O, Zerari F, Grassi J, Maillet S, Conrath M and Couraud JY: Antipeptide polyclonal antibodies that recognize a substance P-binding site in mammalian tissues: A biochemical and immunocy tochemical study. J Neurochem 63: 333-343, 1994
29. Engvall E: Enzyme immunoassay ELISA and EMIT. Methods Enzymol 70: 419-439, 1980.

30. Kasper DL and Zaleznik DF: Gas gangrene, antibiotic associated colitis, and other Clostridial infections. In Stone RM. Harrison's principles of internal medicine self-assessment and board review. Med Pub Div 922-927, 2001.

31. Andrade R, Crisol L, Prado R, Boyano MD, Arluzea J and Arechaga J: Plasma membrane and nuclear envelope integrity during the blebbing stage of apoptosis: A time-lapse study. Biol Cell 102: 25-35, 2009.

32. Shimizu T, Maeno E and Okada Y: Prerequisite role of persisten cell shrinkage in apoptosis of human epithelial cells. Sheng Li Xue Bao 59: 512-516, 2007.

33. Somasekharan SP, Koc M, Morizot A, Micheau O, Sorensen PH, Gaide O, Andera L and Martinou JC: TRAIL promotes membrane blebbing, detachment and migration of cells displaying a dysfunctional intrinsic pathway of apoptosis. Apoptosis 18: 324-336, 2013.

34. Nagata S: Apoptotic DNA fragmentation. Exp Cell Res 256 12-18, 2000.

35. Nagata S, Nagase H, Kawane K, Mukae N and Fukuyama H Degradation of chromosomal DNA during apoptosis. Cell Death Differ 10: 108-116, 2003.

36. Fadok VA, Bratton DL and Henson PM: Phagocyte receptors for apoptotic cells: Recognition, uptake and consequences. J Clin Invest 108: 957-962, 2001

37. Henson PM, Bratton DL and Fadok VA: Apoptotic cell removal. Curr Biol 11: R795-R805, 2001

38. Shacter E, Williams JA, Hinson RM, Senturker S and Lee YJ: Oxidative stress interferes with cancer chemotherapy: Inhibition of lymphoma cell apoptosis and phagocytosis. Blood 96: 307-313, 2000.

39. Niles AL, Moravec RA and Riss TL: In vitro viability and cytotoxicity testing and same-well multi-parametric combinations for high throughput screening. Curr Chem Genomics 3: 33-41, 2009.

40. Proskuryakov SY, Konoplyannikov AG and Gabai VL: Necrosis: A specific form of programmed cell death? Exp Cell Res 283: $1-16,2003$.

41. Kroemer G, Galluzzi L, Vandenabeele P, Abrams J, Alnemri ES, Baehrecke EH, Blagosklonny MV, El-Deiry WS, Golstein P, Green DR, et al: Classification of cell death: Recommendations of the nomenclature committee on cell death. Cell Death Differ 16: 3-11, 2009.

42. Tumasyan N, Sahakyan I, Kocharyan N, Galoyan K and Abrahamyan S: Effect of the physiologically active compounds on rat brain plasticity under the stress. Materials of the XIV International scientific ecological. Conference: 240-242, 2016.

43. Abrahamyan SS, Meliksetyan IB, Chavushyan VA, Aloyan ML and Sarkissian JS: Protective action of snake venom Naja Naja Oxiana at spinal cord hemisection. Ideggyogy Sz 60: 148-153, 2007.

44. Abrahamyan SS, Sahakyan IK, Meliksetyan IB, Tumasyan NV, Badalyan BY and Galoyan AA: Histochemical and immunohistochemical study of morphofunctional state of brain and bone marrow cell structures of rats under stress. N Armenian Med J 5: 60-68, 2011.

45. Abrahamyan SS, Davtyan TK, Khachatryan AR, Tumasyan NV, Sahakyan IK, Harutyunyan HA, Chailyan SG and Galoyan AA: Quantification of the hypothalamic proline rich polypeptide-1 in rat blood serum. Neirokhimiya 31: 47-53, 2014

46. Antonyan AA, Sharoyan SG, Mardanyan SS and Galoyan AA: Proline-rich cytokine from neurosecretory granules: A new natural substrate for dipeptidyl peptidase IV. Neurochem Res 36: 34-38, 2011.

47. Mentlein R: Proline residues in the maturation and degradation of peptide hormones and neuropeptides. FEBS Lett 234: 251-256, 1988.

48. Yaron A and Naider F: Proline-dependent structural and biological properties of peptides and proteins. Crit Rev Biochem Mol Biol 28: 31-81, 1993.

This work is licensed under a Creative Commons Attribution-NonCommercial-NoDerivatives 4.0 International (CC BY-NC-ND 4.0) License. 